\title{
Health Outcomes of Sexual and Gender Minorities After Cancer: A Scoping Review
}

\author{
Mandi Pratt-Chapman ( $\nabla$ mandi@gwu.edu ) \\ George Washington University https://orcid.org/0000-0002-9303-7659 \\ Carlos E. Rodriguez-Diaz \\ The George Washington University Milken Institute of Public Health \\ Ash Alpert \\ University of Rochester Medical Center
}

\section{Research}

Keywords: sexual and gender minorities, LGBTQI, sexual orientation, gender identity, cancer survivorship, patient reported outcomes, QOL

Posted Date: October 12th, 2020

DOI: https://doi.org/10.21203/rs.3.rs-88539/v1

License: (9) (7) This work is licensed under a Creative Commons Attribution 4.0 International License. Read Full License 


\section{Abstract}

Purpose: Cancer research on sexual and gender minority (SGM) populations is gaining momentum. However, literature on patient-reported health outcomes for SGM people with a history of cancer is limited. The purpose of this review was to examine the nature and extent of research regarding patient-reported health outcomes after cancer treatment among SGM populations.

Methods: A systematic search of key words, titles, abstracts, and/or major subjects was conducted in PubMed, Scopus, and CINAHL in September 2019 and in EMBASE in February 2020. Included studies investigated at least one physical, psychosocial, emotional, or functional patient-reported outcome related to cancer diagnosis and/or treatment. Articles that met inclusion criteria were reviewed in their entirety, charted in a Word Table, assessed for quality, and trends within and across studies were reported in addition to each study's results.

Results: Fifty-two studies were included in the final analysis; most were quantitative and focused on people with a history of breast and prostate cancer. Most studies were secondary analyses or cross-sectional studies of convenience samples, limiting generalizability.

Conclusions: A growing literature describes the patient-reported health outcomes of SGM people with a history of cancer. This study summarizes important between-group differences among SGM and heterosexual, cisgender counterparts that are critical for clinicians to consider when providing care. Implications for cancer survivors: Sexual orientation and gender identity are relevant to cancer survivors' health outcomes. Clinicians and researchers can build an evidence base to inform care improvements by collecting data on anatomy, sexual orientation, and gender identity in Electronic Health Records and population-based surveys.

\section{Background}

Lesbian, gay, bisexual, transgender, queer, and/or intersex (LGBTQI) populations, also known as sexual and gender minorities (SGM), have been largely ignored in research until recently. While it is likely that these populations have been included in previous research, lack of data collection about sexual orientation and gender identity and lack of prioritizing the health of these populations has led to limited knowledge of their specific needs. Before the National Academies of Sciences 2011 report, The Health of Lesbian, Gay, Bisexual, and Transgender (LGBT) People: Building a Foundation for Better Understanding, few studies investigated disparities in cancer-related health outcomes based on sexual orientation and no studies investigated the outcomes of gender minority people [1]. In 2016, the National Institutes of Health $(\mathrm{NIH})$ opened a new office dedicated to SGM health research, designating SGM people as a minority population [2]. In 2017, the American Society of Clinical Oncology issued a call to action to reduce cancer health disparities for SGM populations [3].

However, most oncology practitioners have not been trained to address the needs of SGM people, and most cancer centers have yet to institute explicit policies or routine practices to collect sexual orientation and gender-identity data in the electronic medical record, use gender-neutral language on forms, provide SGM-specific support services, and/or require SGM cultural humility training for all staff [4]. Lack of training on the clinical and psychosocial needs of SGM patients perpetuates a system in which patients have to teach their clinicians about how to care for them, resulting in suboptimal care and potentially perpetuating stigmatizing behaviors of clinicians $[5,6]$. Fortunately, cancer research on SGM patients has started to gain momentum. This review aimed to synthesize what is currently known about patient-reported health outcomes of SGM people after definitive cancer treatment to inform clinical practice and identify gaps in the literature to guide future research. A scoping review was selected rather than a systematic review in order to identify a broad range of relevant literature regardless of study design [7].

Notes on terminology: In this manuscript and in the review conducted we used "SGM" as a term meant to encompass diverse people whose gender differs from their sex assigned at birth and/or are not heterosexual. While "SGM" is not a term typically used by LGBTQI people to describe themselves, the authors use this acronym, which has been adopted by the $\mathrm{NIH}$, to be inclusive of a wide range of people, including people who do not identify with the words represented in the acronym "LGBTQI". If a study is focused on a subgroup within the SGM umbrella, the specific subgroup is referred to rather than the broader term "SGM." Furthermore, the authors acknowledge that the term "survivor" is not universally embraced. Our use of the term is for the sake of efficiency of wording. We attempt to, whenever is reasonably efficient, refer to people with a history of cancer rather than a cancer "survivor."

\section{Methods}

\section{Protocol}


No previous protocol for this study has been published. The Arksey and O'Malley [7] five-stage framework for scoping reviews guided this study. The five stages include: identifying the research question; identifying relevant studies; selecting studies; charting the data; and collating, summarizing, and reporting the results (see Figure 1). The search strategy intentionally aimed to cast a wide net before selecting eligible studies for full review. Data was reported following the PRISMA-ScR guidelines [8].

\section{Data sources and search strategy}

A systematic search of key words, titles, abstracts, and/or major subjects was conducted in PubMed, Scopus, and CINAHL in September 2019. The PubMed search required the following key words to be in the title or abstract: (cancer or oncology) and (survivor* or patient) and (homosexual or nonheterosexual or LGBT* or GLBT* or lesbian or gay or bisexual or transgender or transsexual or transexual or "gender queer" or genderqueer or non-binary gender or queer or pansexual or intersex or DSD or "disorders of sex development" or "differences of sex development" or SGM or "sexual and gender minorit*"). Searches in Scopus and CINAHL were similar in approach; however, the Scopus search focused on key words and the CINAHL search used major subject terms (e.g., "GLBT or Queer" and "cancer"). After combining all references, duplicates were manually removed. A hand search of reference lists from review articles was also conducted to ensure all eligible studies included in those reviews were not missed. In February 2020, a fourth search using the PICO builder on EMBASE was conducted using index terms and truncated key words for cancer and survivorship topics plus the search strategy included in the Appendix to identify SGM-relevant studies. The EMBASE search identified entries published through February 21, 2020. Review articles were reviewed in full to identify any studies not found via the systematic searches, and relevant studies were considered for inclusion.

\section{Eligibility criteria}

Studies were limited to articles published in English in the last ten years that were focused on SGM people with a history of a cancer diagnosis. The search was limited to the last decade because very few studies were available on the health outcomes of SGM people after cancer diagnosis and treatment prior to 2010. Furthermore, the attitudes and methods of researchers and clinicians were significantly different a decade ago and we felt this would result in the inclusion of stigmatizing or dyssynchronous work. To be included in the review, studies had to investigate at least one psychosocial, emotional, physical, or functional health-related patient-reported outcome resulting from cancer diagnosis and/or treatment. Commentaries, case studies, abstracts, reviews, provider-focused trainings and interventions, protocol articles without results, and studies conducted prior to the beginning of cancer therapy were excluded. Studies focusing on risks or prevalence of cancer among SGM, care experiences or satisfaction with care, patient disclosure of SGM status, communication with providers, or social support needs were excluded unless the study also reported a physical, psychosocial, emotional, or functional patientreported health outcome, as well. Studies of differential survival or progression-free survival comparing SGM to heterosexual populations were not excluded: there simply were no studies to reference in this review.

\section{Results}

\section{Study selection}

Database searches for peer-reviewed articles focused on health outcomes among SGM after definitive treatment for cancer yielded 242 entries in PubMed, 340 in Scopus, 46 in CINAHL, and 115 in EMBASE. All included articles were required to have SGM people with a history of cancer as a primary focus of the study. Author MPC conducted a review of titles in Excel for these 743 entries. A manual review of reference lists of review articles was conducted to ensure no studies were missed in systematic searches, adding additional articles for abstract review $(n=23)$. Duplicates $(n=196)$ and articles that did not meet eligibility criteria were removed $(n=365$ during title review; $n=140$ during abstract review). Full text articles $(n=65)$ were reviewed for compliance with the inclusion criteria; reasons for exclusion after full-text review are provided in Figure 2 . The full-text articles included in this study were $n=52$.

\section{Study characteristics}

Most studies were studies of people with a history of breast or prostate cancer and were focused on disparities based on sexual orientation. One study focused on people who were diagnosed with cancer during adolescence and young adulthood (AYA) and one on people with a history of colorectal cancer. Most studies were conducted in the U.S., Australia, and Canada. See Table 1 for general characteristics of included studies. 
Table 1

Characteristics of included studies $(n=52)$

\begin{tabular}{|c|c|}
\hline Country where study takes place* & Number of studies \\
\hline Australia & 6 \\
\hline Canada & 9 \\
\hline Ireland & 1 \\
\hline New Zealand & 1 \\
\hline Romania & 1 \\
\hline United States & 41 \\
\hline United Kingdom & 2 \\
\hline \multicolumn{2}{|l|}{ Reports outcomes of } \\
\hline AYA SGM & 1 \\
\hline SGM broadly & 9 \\
\hline MSM & 20 \\
\hline WSW & 23 \\
\hline Transgender people & 4 \\
\hline Intersex people & 0 \\
\hline \multicolumn{2}{|l|}{ Study design } \\
\hline Mixed methods & 2 \\
\hline Qualitative & 10 \\
\hline Quantitative & 39 \\
\hline \multicolumn{2}{|l|}{ Cancer focus* } \\
\hline AYA & 1 \\
\hline Breast & 22 \\
\hline Colorectal & 1 \\
\hline Prostate & 19 \\
\hline Various cancers & 8 \\
\hline *Not mutually exclusive & \\
\hline
\end{tabular}

\section{Data charting: Summary of studies}

Table 2 was used as a template for data charting. Studies were sorted by the following demographic groups: adolescent and young adults and studies focused on those diagnosed with breast, prostate, or multiple cancers, respectively. Lead author and year, location, population of interest including any comparison group(s) when relevant, type of study, design, outcomes, and critical appraisal of each study are reported in Table 2. Critical appraisal consisted of a review of sample recruitment strategy, diversity of the sample (generalizability), study design, use of validated tools (for quantitative studies), innovation, and significance. All authors participated in data abstraction and table review for consistency. 
Table 2

Summary of Studies of Patient Reported Outcomes from SGM People Diagnosed with Cancer

\begin{tabular}{|c|c|c|c|c|c|c|}
\hline Study & Location & Population & $\begin{array}{l}\text { Type of } \\
\text { study }\end{array}$ & Study design & $\begin{array}{l}\text { Outcomes } \\
\text { reported }\end{array}$ & Critical appraisal \\
\hline \multicolumn{7}{|c|}{ AYA cancers } \\
\hline $\begin{array}{l}\text { Russell et } \\
\text { al. (2016) } \\
\text { [9] }\end{array}$ & U.S. & $\begin{array}{l}\text { Adolescent and } \\
\text { young adult (AYA) } \\
\text { cancer survivors } \\
(n=56) \text { including } \\
\text { SGM }(n=22) \text { and } \\
\text { heterosexual } \\
(n=34) \text { survivors }\end{array}$ & Qualitative & $\begin{array}{l}\text { AYA survivors } \\
\text { were interviewed } \\
\text { by telephone; } \\
\text { asked about pre- } \\
\text { and post- } \\
\text { diagnosis } \\
\text { thoughts } \\
\text { regarding } \\
\text { relationships, } \\
\text { parenthood, } \\
\text { fertility, and how/ } \\
\text { if fertility risks } \\
\text { were conveyed to } \\
\text { them during } \\
\text { treatment. }\end{array}$ & $\begin{array}{l}\text { Both SGM and } \\
\text { heterosexual } \\
\text { survivors reported } \\
\text { post-diagnosis } \\
\text { dating challenges. } \\
\text { Straight survivors } \\
\text { had greater } \\
\text { fertility concerns } \\
\text { (p<.05). SGM } \\
\text { survivors were } \\
\text { more likely to be } \\
\text { open to raising a } \\
\text { non-biological } \\
\text { child or never } \\
\text { parenting. Straight } \\
\text { survivors were } \\
\text { more likely to be } \\
\text { unsatisfied with } \\
\text { information } \\
\text { provided about } \\
\text { fertility, but SGM } \\
\text { survivors were just } \\
\text { as likely to not be } \\
\text { informed about } \\
\text { potential infertility } \\
\text { risks. }\end{array}$ & $\begin{array}{l}\text { Strengths: Only } \\
\text { AYA cancer } \\
\text { survivorship study } \\
\text { known to date that } \\
\text { examines } \\
\text { differences by } \\
\text { sexual orientation; } \\
\text { diversity of types } \\
\text { of cancer and } \\
\text { treatment } \\
\text { modalities. } \\
\text { Limitations: Small } \\
\text { sample size limits } \\
\text { subgroup } \\
\text { analyses; mostly } \\
\text { white sample. }\end{array}$ \\
\hline
\end{tabular}

\section{Breast cancer}

\begin{tabular}{|c|c|c|c|c|c|}
\hline $\begin{array}{l}\text { Bazzi et al. } \\
\text { (2018) [10] }\end{array}$ & U.S. & $\begin{array}{l}\text { Breast cancer } \\
\text { survivors: }(n=339 \\
\text { heterosexual } \\
\text { women, } n=201 \\
\text { WSW) }\end{array}$ & Quantitative & $\begin{array}{l}\text { Cross-sectional } \\
\text { national survey } \\
\text { recruited from } \\
\text { Army of Women } \\
\text { using } \\
\text { multivariable } \\
\text { regression with } \\
\text { primary outcome } \\
\text { as resilience. }\end{array}$ & $\begin{array}{l}\text { Sexual orientation } \\
\text { was not } \\
\text { associated with } \\
\text { resilience, but } \\
\text { WSW who were } \\
\text { unemployed had } \\
\text { less resilience } \\
\text { than employed } \\
\text { counterparts } \\
\text { whereas } \\
\text { heterosexual } \\
\text { women had no } \\
\text { differences based } \\
\text { on employment } \\
\text { status. }\end{array}$ \\
\hline
\end{tabular}

Strengths: Large sample diverse in socioeconomic status, cancer stage, and type of treatment; use of validated scales (ISEL-6, Mini-MAC, RS-14).

Limitations: Sample is partially one of convenience, mostly white, and highly educated; self-report data; cross-sectional design.

\begin{tabular}{|c|c|c|c|c|}
\hline $\begin{array}{l}\text { Boehmer et } \\
\text { al. }(2011) \\
\text { [11] }\end{array}$ & $\begin{array}{l}\text { U.S. } \\
\text { (Massachusetts } \\
\text { Cancer } \\
\text { Registry) }\end{array}$ & $\begin{array}{l}\text { Nonmetastatic } \\
\text { breast cancer } \\
\text { survivors }(n=257 \\
\text { heterosexual } \\
\text { women, } n=69 \\
\text { WSW) }\end{array}$ & Quantitative & $\begin{array}{l}\text { Multinomial } \\
\text { regression with } \\
\text { weighting of } \\
\text { subpopulations; } \\
\text { primary outcome } \\
\text { was weight.* }\end{array}$ \\
\hline
\end{tabular}

While WSW in the
general
population were
more likely to be
overweight and
obese, WSW
cancer survivors
were not
statistically more
likely to be
overweight/ obese
than heterosexual
counterparts. This
finding suggests
that WSW may be
motivated by
cancer to reduce
overweight.

While WSW in the more likely to be overweight and obese, WSW were not statistically more likely to be overweight/ obese than heterosexual finding that WSW may be motivated by cancer to redu
Strengths: Recruitment from a populationbased registry; diversity of education, socioeconomic status, cancer stage, and treatment modality. Limitations: Data reported from one state; self-report data; potential bias in reporting weight; crosssectional design. 


\begin{tabular}{|c|c|c|c|c|c|}
\hline $\begin{array}{l}\text { Boehmer et } \\
\text { al. }(2012) \\
\text { [12] }\end{array}$ & $\begin{array}{l}\text { U.S. } \\
\text { (Massachusetts } \\
\text { Cancer Registry } \\
\text { + national } \\
\text { convenience } \\
\text { sample) }\end{array}$ & $\begin{array}{l}\text { Nonmetastatic } \\
\text { breast cancer } \\
\text { survivors }(n=257 \\
\text { heterosexual } \\
\text { women, } n=181 \\
\text { WSW) }\end{array}$ & Quantitative & $\begin{array}{l}\text { Least square } \\
\text { regression } \\
\text { separately run for } \\
\text { physical } \\
\text { component and } \\
\text { mental } \\
\text { component } \\
\text { summary scales } \\
\text { of the SF-12 on } \\
\text { each demographic } \\
\text { and clinical } \\
\text { characteristic, } \\
\text { controlling for } \\
\text { sexual } \\
\text { orientation.* }\end{array}$ & $\begin{array}{l}\text { Overall, WSW and } \\
\text { heterosexual } \\
\text { women were } \\
\text { comparable in } \\
\text { QOL. WSW from } \\
\text { the registry were } \\
\text { more likely to be } \\
\text { white, educated, } \\
\text { and employed. } \\
\text { Only WSW with } \\
\text { low/ middle } \\
\text { income had worse } \\
\text { physical health } \\
\text { than heterosexual } \\
\text { counterparts. } \\
\text { WSW who } \\
\text { experienced more } \\
\text { discrimination } \\
\text { reported worse } \\
\text { physical health. }\end{array}$ \\
\hline
\end{tabular}

Strengths: Use of validated scale (SF-12)

Limitations:

Sample is partially one of

convenience, mostly white, and highly educated; self-report data; cross-sectional design.

\begin{tabular}{|c|c|c|}
\hline $\begin{array}{l}\text { Boehmer et } \\
\text { al. (2012) } \\
\text { [13] }\end{array}$ & U.S. & $\begin{array}{l}\text { Nonmetastatic } \\
\text { breast cancer } \\
\text { survivors }(n=257 \\
\text { heterosexual } \\
\text { women, } n=181 \\
\text { WSW) }\end{array}$ \\
\hline
\end{tabular}

$\begin{array}{ll}\text { Quantitative } & \text { Least square } \\ & \text { regression was } \\ & \text { used for each } \\ \text { demographic and } & \text { clinical } \\ & \text { characteristic, } \\ & \text { controlling for } \\ \text { sexual } \\ \text { orientation.* }\end{array}$

WSW appeared more resilient than heterosexual counterparts with some exceptions: unemployed WSW experienced greater anxiety than heterosexual women, and WSW who underwent radiation therapy were more depressed than heterosexual counterparts. WSW reported higher rates of discrimination, which was associated with more depression.
Strengths: Use of a validated measure (HADS); sample size.

Limitations: Sample is partially one of convenience, mostly white, and highly educated; self-report data; cross-sectional design; low percentage of variance explained by models.

\begin{tabular}{|c|c|c|c|c|}
\hline $\begin{array}{l}\text { Boehmer et } \\
\text { al. }(2012) \\
{[14]}\end{array}$ & U.S. & $\begin{array}{l}\text { Nonmetastatic } \\
\text { WSW breast } \\
\text { cancer survivors } \\
\text { without } \\
\text { recurrence }(n=22)\end{array}$ & Qualitative & $\begin{array}{l}\text { Semi-structured } \\
\text { telephone } \\
\text { interviews ranging } \\
\text { from } 30-150 \\
\text { minutes; coding } \\
\text { based on } \\
\text { grounded theory. }\end{array}$ \\
\hline
\end{tabular}

Themes included: 1) Breast cancer is a women's, not a lesbian, issue; 2) I can manage my identity in the context of breast cancer; 3) I am better off than my heterosexual counterparts (e.g., less emphasis on body image, empathic female partners)

\section{Strengths: \\ Adaptations to interview guide to maximize neutrality. Limitations: Convenience sample, mostly white, and highly educated; self- report data.}

\begin{tabular}{|c|c|c|}
\hline $\begin{array}{l}\text { Boehmer et } \\
\text { al. (2012) } \\
{[15]}\end{array}$ & U.S. & $\begin{array}{l}\text { Nonmetastatic } \\
\text { WSW breast } \\
\text { cancer cases anc } \\
\text { heterosexual } \\
\text { controls ( } \mathrm{n}=85 \\
\text { cases, } \mathrm{n}=85 \\
\text { controls) }\end{array}$ \\
\hline
\end{tabular}

\section{Quantitative}

Using a

conceptual

framework for

heterosexual

breast cancer

survivors,

generalized

estimating

equations

identified

explanatory

factors of sexual

function between
Sexual function was predicted by self-perception of sexual attraction and urogenital symptoms for both WSW and heterosexual women; for partnered women, postmenopausal status and dyadic cohesion was
Strengths: Casecontrol design; use of validated scale (SF-12); amount of variance explained by models (nearly half). Limitations: Convenience sample, mostly white, and highly educated; selfreport data; use of a sexual measure 


\begin{tabular}{|c|c|c|c|c|c|c|}
\hline & & & & $\begin{array}{l}\text { cases and } \\
\text { controls.* }\end{array}$ & $\begin{array}{l}\text { predictive of } \\
\text { sexual function; } \\
\text { HRQOL was less } \\
\text { explanatory for } \\
\text { WSW's sexual } \\
\text { function } \\
\text { compared to } \\
\text { heterosexual } \\
\text { women. }\end{array}$ & $\begin{array}{l}\text { designed for } \\
\text { heterosexual } \\
\text { women (FSFI); } \\
\text { cross-sectional } \\
\text { design. }\end{array}$ \\
\hline $\begin{array}{l}\text { Boehmer et } \\
\text { al. (2013) } \\
\text { [16] }\end{array}$ & $\begin{array}{l}\text { U.S. } \\
\text { (Massachusetts } \\
\text { Cancer Registry } \\
\text { + national } \\
\text { convenience } \\
\text { sample) }\end{array}$ & $\begin{array}{l}\text { Nonmetastatic } \\
\text { breast cancer } \\
\text { survivors }(n=257 \\
\text { heterosexual } \\
\text { women, } n=181 \\
\text { WSW) }\end{array}$ & Quantitative & $\begin{array}{l}\text { Multiple } \\
\text { regression models } \\
\text { with stepwise } \\
\text { variable selection } \\
(p=.10) ; \text { model fit } \\
\text { reported with } \mathrm{R}^{2} \\
\text { statistics.*}\end{array}$ & $\begin{array}{l}\text { WSW had less } \\
\text { cognitive } \\
\text { avoidance coping } \\
\text { than heterosexual } \\
\text { peers. Social } \\
\text { support and } \\
\text { having a partner } \\
\text { were more } \\
\text { strongly } \\
\text { associated with } \\
\text { better mental and } \\
\text { physically health, } \\
\text { respectively, for } \\
\text { WSW v. } \\
\text { heterosexual } \\
\text { counterparts. }\end{array}$ & $\begin{array}{l}\text { Strengths: Use of } \\
\text { validated scales } \\
\text { (TPS, ISEL-6, Mini- } \\
\text { MAC, BFS); large } \\
\text { amount of } \\
\text { variance explained } \\
\text { in models. } \\
\text { Limitations: } \\
\text { Sample partially } \\
\text { one of } \\
\text { convenience, } \\
\text { mostly white, and } \\
\text { highly educated; } \\
\text { cross-sectional } \\
\text { design; self-report } \\
\text { data. }\end{array}$ \\
\hline $\begin{array}{l}\text { Boehmer et } \\
\text { al. (2013) } \\
\text { [17] }\end{array}$ & $\begin{array}{l}\text { U.S. } \\
\text { (Massachusetts } \\
\text { Cancer Registry } \\
\text { + national } \\
\text { convenience } \\
\text { sample) }\end{array}$ & $\begin{array}{l}\text { Nonmetastatic } \\
\text { WSW breast } \\
\text { cancer survivors } \\
\text { ( } n=161 \text { lesbians, } \\
n=19 \text { bisexual } \\
\text { women) }\end{array}$ & Quantitative & $\begin{array}{l}\text { Multiple } \\
\text { regression models } \\
\text { with stepwise } \\
\text { variable selection } \\
(\mathrm{p}=.10) ; \text { fit } \\
\text { reported with } \mathrm{R}^{2} \\
\text { statistics.* }\end{array}$ & $\begin{array}{l}\text { Lesbian and } \\
\text { bisexual women } \\
\text { did not differ in } \\
\text { physical or mental } \\
\text { health; however, } \\
\text { women with } \\
\text { female partners } \\
\text { fared better than } \\
\text { women who were } \\
\text { with male partners } \\
\text { or unpartnered. }\end{array}$ & $\begin{array}{l}\text { Strengths: Use of } \\
\text { validated scales } \\
\text { (TPS, Mini-MAC, } \\
\text { QLQ-BR23, SF-12); } \\
\text { large amount of } \\
\text { variance explained } \\
\text { in models. } \\
\text { Limitations: Small } \\
\text { bisexual sample } \\
\text { (n=19); sample } \\
\text { partially one of } \\
\text { convenience, } \\
\text { mostly white, and } \\
\text { highly educated; } \\
\text { cross-sectional } \\
\text { design; self-report } \\
\text { data. }\end{array}$ \\
\hline $\begin{array}{l}\text { Boehmer et } \\
\text { al. (2013) } \\
\text { [18] }\end{array}$ & $\begin{array}{l}\text { U.S. } \\
\text { (Massachusetts } \\
\text { Cancer Registry } \\
\text { + national } \\
\text { convenience } \\
\text { sample) }\end{array}$ & $\begin{array}{l}\text { Nonmetastatic } \\
\text { breast cancer } \\
\text { survivors }(n=257 \\
\text { heterosexual } \\
\text { women, } n=181 \\
\text { WSW) }\end{array}$ & Quantitative & $\begin{array}{l}\text { Multiple } \\
\text { regression (for } \\
\text { linear variables) } \\
\text { and logistic } \\
\text { regression (for } \\
\text { dichotomous } \\
\text { variables) models } \\
\text { with stepwise } \\
\text { variable selection } \\
(p=.10) ; \text { fit } \\
\text { reported with } \mathrm{R}^{2} \\
\text { statistics or } \\
\text { pseudo-R }{ }^{2} \\
\text { statistics. }^{*}\end{array}$ & $\begin{array}{l}\text { WSW generally } \\
\text { had lower blood } \\
\text { pressure and } \\
\text { fewer } \\
\text { comorbidities } \\
\text { than heterosexual } \\
\text { counterparts. } \\
\text { However, the } \\
\text { impact of } \\
\text { mastectomy and } \\
\text { radiation in } \\
\text { worsening arm } \\
\text { symptoms was } \\
\text { twice as strong for } \\
\text { WSW compared to } \\
\text { heterosexual } \\
\text { peers. Having } \\
\text { health insurance } \\
\text { was associated } \\
\text { with fewer side } \\
\text { effects, an effect } \\
\text { three times } \\
\text { stronger for Wsw } \\
\text { v. heterosexual } \\
\text { peers. }\end{array}$ & $\begin{array}{l}\text { Strengths: Use of } \\
\text { validated scale } \\
\text { (QLQ-BR23). } \\
\text { Limitations: } \\
\text { Sample partially } \\
\text { one of } \\
\text { convenience, } \\
\text { mostly white, and } \\
\text { highly educated; } \\
\text { cross-sectional } \\
\text { design; self-report } \\
\text { data. }\end{array}$ \\
\hline
\end{tabular}




\begin{tabular}{|c|c|c|c|c|}
\hline $\begin{array}{l}\text { Boehmer et } \\
\text { al. (2014) } \\
\text { [19] }\end{array}$ & U.S. & $\begin{array}{l}\text { Convenience } \\
\text { sample of WSW } \\
\text { ( } n=85 \text { with history } \\
\text { of cancer, } n=85 \\
\text { never-diagnosed) }\end{array}$ & Quantitative & $\begin{array}{l}\text { Case control study } \\
\text { examining sexual } \\
\text { frequency, desire, } \\
\text { ability to reach } \\
\text { orgasm and pain } \\
\text { using multiple } \\
\text { general linear } \\
\text { models or logistic } \\
\text { regression for } \\
\text { categorical } \\
\text { variables.* }\end{array}$ \\
\hline
\end{tabular}

Groups did not differ in risk of sexual

dysfunction or overall

functioning, but cases had lower sexual frequency, less desire and ability to reach orgasm, and more pain during sex.
Strengths: Casecontrol design. Limitations: Use of a sexual measure designed for heterosexual women (FSFI); cross-sectional design.

\begin{tabular}{|c|c|c|c|c|}
\hline $\begin{array}{l}\text { Boehmer et } \\
\text { al. (2015) } \\
\text { [20] }\end{array}$ & U.S. & $\begin{array}{l}\text { Convenience } \\
\text { sample of WSW } \\
\text { ( } n=85 \text { with history } \\
\text { of cancer, } n=85 \\
\text { never-diagnosed) }\end{array}$ & Quantitative & $\begin{array}{l}\text { Case control study } \\
\text { assessing self- } \\
\text { reported physical } \\
\text { activity, fruit and } \\
\text { vegetable intake, } \\
\text { weight, QOL, } \\
\text { anxiety and } \\
\text { depression using } \\
\text { multiple general } \\
\text { linear models or } \\
\text { logistic regression } \\
\text { for categorical } \\
\text { variables.* }\end{array}$ \\
\hline
\end{tabular}

Groups did not differ in health behaviors, BMI, QOL, anxiety, and depression. Both groups were a majority overweight or obese, around 13$15 \%$ reporting depression and $37-45 \%$ reporting anxiety. More physical activity correlated with lower weight, less depression, and better mental health in both WSW groups.
Strengths: Casecontrol design; use of validated scales (HADS, SF-12). Limitations: Crosssectional design.

\begin{tabular}{|c|c|c|}
\hline $\begin{array}{l}\text { Boehmer et } \\
\text { al. (2016) } \\
{[21]}\end{array}$ & U.S. & $\begin{array}{l}\text { Sample recruited } \\
\text { from prior } \\
\text { registry-based } \\
\text { study plus a } \\
\text { sample drawn } \\
\text { from the Army of } \\
\text { Women ( } \mathrm{n}=167 \\
\text { matched breast } \\
\text { cancer survivor/ } \\
\text { caregiver dyads) }\end{array}$ \\
\hline
\end{tabular}

Quantitative

Multiple logistic
regression on fear
of recurrence
(FOR) using
propensity score
matching ( $\mathrm{p}<.10)$.
Simultaneous
equation models
were used to
avoid endogeneity,
since primary
outcomes were
patient and
caregiver
influence on each
others' FOR.

Survivor FOR was explained by years since diagnosis, co-residence with partner, caregiver receiving counseling, survivor ISEL scores, receipt of chemotherapy, and sexual orientation. Caregiver FOR was explained by years since survivor's diagnosis, caregiver's discrimination score, caregiver's social support, survivor's antiestrogen therapy, survivor's comorbidities, and sexual orientation. For both groups, caregiver FOR influenced survivor FOR, but not vice versa. Between groups, WSW survivors and caregivers had less FOR than heterosexual survivors and caregivers.

Strengths: Study design allowed for modeling of causal relationships for FOR. Limitations: Caregiver gender and sexual orientation were not considered; sample lacked racial diversity. 


$\begin{array}{lll}\begin{array}{l}\text { Boehmer et } \\ \text { al. (2018) }\end{array} & \text { U.S. } & \text { Sample recruited } \\ \text { [22] } & \text { from prior } \\ & \text { registry-based } \\ & \text { study plus a } \\ & \text { sample drawn } \\ & \text { from the Army of } \\ & \text { Women (n=167 } \\ & \text { matched breast } \\ & \text { cancer survivor/ } \\ & \text { caregiver dyads) }\end{array}$

Quantitative Multiple logistic regression on stress using propensity score matching $(p<.10)$. Simultaneous equation models were used to avoid endogeneity, since primary outcomes were patient and caregiver influence on each others' stress.
WSW survivor and caregiver stress were similar to heterosexual peers; however, WSW dyads showed interdependent stress associations where heterosexual dyads did not.
Strengths: Use of validated scales (ISEL, MSPS, DAS). Limitations: Cross-sectional design.

\begin{tabular}{|c|c|c|}
\hline $\begin{array}{l}\text { Boehmer et } \\
\text { al. (2019) } \\
{[23]}\end{array}$ & U.S. & $\begin{array}{l}\text { BRFSS } \\
\text { respondents who } \\
\text { had a past } \\
\text { diagnosis of } \\
\text { cancer ( } n=68,593 \\
\text { heterosexual } \\
\text { women, } n=1,931 \\
\text { WSW) }\end{array}$ \\
\hline
\end{tabular}

Quantitative

Secondary data analysis of 20142017 years of BRFSS data. Survivors were categorized with an access deficit if any one of the following were true: no health insurance, delaying care, avoiding care due to cost, and lacking a trusted physician. Weighted analysis computed odds ratios and $95 \%$ confidence intervals using cumulative logit models and logistic regression, taking into account confounders.
WSW reported more access to care deficitsincluding lack of health care coverage, having no personal physician, avoiding care due to cost, and being without an annual visit-- compared to heterosexual peers $(p<.0001)$. WSW with deficits had poorer physical and mental QOL and trouble concentrating compared to heterosexual peers.

\section{Strengths: Use of a large, population-based sample. Limitations: Small WSW sample sizes prevented subanalyses.}

\begin{tabular}{|c|c|c|c|c|c|c|}
\hline $\begin{array}{l}\text { Boehmer et } \\
\text { al. (2020) } \\
\text { [24] }\end{array}$ & U.S. & $\begin{array}{l}\text { Non-metastatic, } \\
\text { non-recurrent } \\
\text { breast cancer } \\
\text { survivors of } \\
\text { various sexual } \\
\text { orientations } \\
(n=167)\end{array}$ & Quantitative & $\begin{array}{l}\text { Breast cancer } \\
\text { survivors surveyed } \\
\text { by telephone were } \\
\text { assessed for QOL; } \\
\text { propensity score } \\
\text { weighting } \\
\text { accounted for } \\
\text { differences by } \\
\text { sexual orientation } \\
\text { in age and length } \\
\text { of dyadic } \\
\text { relationships; } \\
\text { simultaneous } \\
\text { equation models } \\
\text { assessed dyads. }\end{array}$ & $\begin{array}{l}\text { There were no } \\
\text { differences in QOL } \\
\text { by sexual } \\
\text { orientation 6-7 } \\
\text { years post- } \\
\text { diagnosis; sexual } \\
\text { minority dyads } \\
\text { showed greater } \\
\text { dependence on } \\
\text { partner QOL } \\
\text { scores than } \\
\text { heterosexual } \\
\text { dyads }\end{array}$ & $\begin{array}{l}\text { Strengths: } \\
\text { Propensity score } \\
\text { weighting; use of } \\
\text { simultaneous } \\
\text { equation } \\
\text { modeling; dyadic } \\
\text { assessment; use } \\
\text { of validated } \\
\text { measures (SF-12, } \\
\text { ISEL-SF, MSPSS). } \\
\text { Limitations: Cross } \\
\text { sectional design; } \\
\text { small comparative } \\
\text { heterosexual } \\
\text { group. }\end{array}$ \\
\hline
\end{tabular}

\begin{tabular}{|c|c|c|c|c|c|c|}
\hline $\begin{array}{l}\text { Brown \& } \\
\text { McElroy } \\
(2018) \text { [25] }\end{array}$ & U.S./ & $\begin{array}{l}\text { SGM breast } \\
\text { cancer survivors } \\
(n=68) \text { ages 18- } \\
75\end{array}$ & $\begin{array}{l}\text { Mixed } \\
\text { methods }\end{array}$ & $\begin{array}{l}\text { Purposive and } \\
\text { referral sampling } \\
\text { were used to } \\
\text { recruit SM breast } \\
\text { cancer survivors } \\
\text { to complete an } \\
\text { online survey. } \\
\text { Bivariate analyses } \\
\text { were conducted } \\
\text { using cross- } \\
\text { tabulations and } \\
\text { chi-square tests to } \\
\text { determine }\end{array}$ & $\begin{array}{l}25 \% \text { of the sample } \\
\text { elected to "go flat" } \\
\text { or not receive } \\
\text { breast } \\
\text { reconstruction. } \\
\text { "Flattopers" were } \\
\text { more likely to } \\
\text { identify as } \\
\text { genderqueer, be } \\
\text { out to their } \\
\text { providers, and } \\
\text { participate in SGM } \\
\text { support groups }\end{array}$ & $\begin{array}{l}\text { Strengths: This is } \\
\text { one of only } 2 \\
\text { known studies to } \\
\text { report } \\
\text { transgender/ } \\
\text { genderqueer } \\
\text { outcomes of } \\
\text { breast cancer in } \\
\text { their own words; } \\
\text { use of a previously } \\
\text { developed scale } \\
\text { (BITS). } \\
\text { Limitations: Cross- }\end{array}$ \\
\hline
\end{tabular}




\begin{tabular}{|c|c|c|c|c|c|c|}
\hline & & & & $\begin{array}{l}\text { differences } \\
\text { between those } \\
\text { electing to choose } \\
\text { bilateral } \\
\text { mastectomy } \\
\text { without } \\
\text { reconstruction } \\
\text { versus those who } \\
\text { did not. NVIVO } \\
\text { was used for } \\
\text { thematic analysis } \\
\text { of open-text } \\
\text { questions. }\end{array}$ & $\begin{array}{l}\text { compared to the } \\
\text { rest of the sample. } \\
\text { There were not } \\
\text { significant } \\
\text { between-group } \\
\text { differences for the } \\
\text { BITS. Qualitative } \\
\text { themes from } \\
\text { open-text } \\
\text { responses } \\
\text { included reasons } \\
\text { for "going flat," } \\
\text { interactions with } \\
\text { health care } \\
\text { providers, gender } \\
\text { policing/ } \\
\text { heterosexism } \\
\text { during treatment, } \\
\text { and mixed } \\
\text { physical and } \\
\text { emotional } \\
\text { outcomes of } \\
\text { treatment choices. }\end{array}$ & $\begin{array}{l}\text { sectional design; } \\
\text { predominantly } \\
\text { white sample. }\end{array}$ \\
\hline $\begin{array}{l}\text { Jabson, } \\
\text { Donatelle, \& } \\
\text { Bowen } \\
(2011) \text { [26] }\end{array}$ & U.S. & $\begin{array}{l}\text { SM breast cancer } \\
\text { survivors }(n=68)\end{array}$ & Quantitative & $\begin{array}{l}\text { Purposive } \\
\text { sampling via } \\
\text { known WSW } \\
\text { gathering places } \\
\text { recruited WSW } \\
\text { breast cancer } \\
\text { survivors to } \\
\text { participate in an } \\
\text { online survey } \\
\text { focused on } \\
\text { perceived } \\
\text { discrimination, } \\
\text { social support, } \\
\text { stress, and QOL; } \\
\text { regression models } \\
\text { examined } \\
\text { predictive value of } \\
\text { independent } \\
\text { variables } \\
\text { (perceived } \\
\text { discrimination, } \\
\text { support, stress) on } \\
\text { QOL. }\end{array}$ & $\begin{array}{l}\text { Most WSW (92\%) } \\
\text { reported being } \\
\text { treated similar to } \\
\text { heterosexual } \\
\text { peers. Thirty-nine } \\
\text { percent of } \\
\text { participants } \\
\text { indicated they } \\
\text { were perceived as } \\
\text { heterosexual by } \\
\text { their health care } \\
\text { team. Perceived } \\
\text { social support and } \\
\text { perceived } \\
\text { discrimination } \\
\text { were statistically } \\
\text { significant } \\
\text { predictors of } \\
\text { better QOL, } \\
\text { because perceived } \\
\text { heterosexuality } \\
\text { was a construct of } \\
\text { the discrimination } \\
\text { scale and } \\
\text { associated with } \\
\text { better QOL. }\end{array}$ & $\begin{array}{l}\text { Strengths: use of } \\
\text { validated scales } \\
\text { (BSS, QOL-CSV, } \\
\text { PSS) and } \\
\text { adaptation of } \\
\text { previous } \\
\text { discrimination } \\
\text { scale that showed } \\
\text { strong reliability } \\
\text { (a=.75). } \\
\text { Limitations: } \\
\text { Predominantly } \\
\text { white, educated, } \\
\text { insured, partnered, } \\
\text { economically } \\
\text { stable } \\
\text { convenience } \\
\text { sample; missing } \\
\text { data may skew } \\
\text { results toward the } \\
\text { null. }\end{array}$ \\
\hline $\begin{array}{l}\text { Jabson et } \\
\text { al.,(2011) } \\
\text { [27] }\end{array}$ & U.S. & $\begin{array}{l}\text { Breast cancer } \\
\text { survivors ( } n=143 \\
\text { heterosexual, } \\
n=61 \text { WSW } \\
\text { women) }\end{array}$ & Quantitative & $\begin{array}{l}\text { Convenience } \\
\text { sample of } 204 \\
\text { breast cancer } \\
\text { survivors were } \\
\text { recruited to an } \\
\text { online survey. } \\
\text { Means and } \\
\text { standard } \\
\text { deviations of } \\
\text { global QOL and } \\
\text { four subscales } \\
\text { (physical, } \\
\text { psychological, } \\
\text { social, and } \\
\text { spiritual well- } \\
\text { being) were } \\
\text { compared by } \\
\text { sexual orientation } \\
\text { (heterosexual v. } \\
\text { WSW). }\end{array}$ & $\begin{array}{l}\text { Overall QOL as } \\
\text { well as subscales } \\
\text { of QOL did not } \\
\text { statistically differ } \\
\text { between groups. }\end{array}$ & $\begin{array}{l}\text { Strength: Use of } \\
\text { validated scale } \\
\text { (QOL-CSV). } \\
\text { Limitation: } \\
\text { Predominantly } \\
\text { white, educated, } \\
\text { insured, partnered, } \\
\text { economically } \\
\text { stable } \\
\text { convenience } \\
\text { sample; missing } \\
\text { data may skew } \\
\text { results toward the } \\
\text { null. }\end{array}$ \\
\hline Jabson \& & U.S. & Breast cancer & Quantitative & Convenience & WSW had higher & Strength: Use of \\
\hline
\end{tabular}




$\begin{array}{ll}\text { Bowen } & \text { survivors }(n=143 \\ \text { (2014) [28] } & \text { heterosexual } \\ & \text { women, } n=68 \\ & \text { WSW })\end{array}$

sample of 211

breast cancer

survivors were

recruited to an

online survey.

Means and

standard

deviations of

perceived stress

were compared by

sexual orientation. perceived stress than heterosexual peers in regression modeling. validated PSS.

Limitation:

Predominantly white, educated, insured, partnered, economically stable convenience sample; missing data may skew results toward the null.

\begin{tabular}{|c|c|c|}
\hline $\begin{array}{l}\text { Jabson, } \\
\text { Farmer, \& } \\
\text { Bowen } \\
\text { (2015) [29] }\end{array}$ & U.S. & $\begin{array}{l}\text { Cancer survivors } \\
\text { participating in } \\
\text { the NHANES from } \\
2001-2010 \\
(n=576 \\
\text { heterosexual } \\
\text { women, } n=26 \\
\text { WSW). }\end{array}$ \\
\hline
\end{tabular}

Kamen et

[30]
U.S.
SM breast cancer

survivors $(n=201)$

recruited through

the Army of

Women $(n=172$

lesbian, $n=29$

bisexual women).

$\begin{array}{ll}\text { Quantitative } & \text { NHANES data } \\ & \text { from 2001-2010 } \\ & \text { were pooled and } \\ & 602 \text { cancer } \\ & \text { survivors were } \\ \text { identified. } & \text { Between group } \\ & \text { (WSW v. } \\ \text { heterosexual) } & \text { characteristics, } \\ \text { health behaviors, } & \text { and self-reported } \\ & \text { health were } \\ & \text { compared using } \\ \text { chi-square and t- } & \text { tests; logistic } \\ \text { regression was } & \text { used to compare } \\ \text { WSW v. } \\ \text { heterosexual } \\ \text { aORs; propensity } \\ \text { score adjustment } \\ \text { used for } \\ \text { sociodemographic } \\ \text { variables. }\end{array}$

$4.3 \%$ of the sample selfidentified as WSW. WSW were 2.5 times more likely to report past illicit drug use and $60 \%$ less likely to report current health as good compared to heterosexual peers.

Strengths: Population-based sample. Limitations: Small sample of sexual minority cancer survivors in NHANES data due to lack of data collection of sexual orientation from 2001-2006 limited the power of the study.

\begin{tabular}{|c|c|}
\hline $\begin{array}{l}\text { SM women with } \\
\text { stage } 0 \text {-III breast }\end{array}$ & $\begin{array}{l}\text { Discrimination, } \\
\text { resilience, and }\end{array}$ \\
\hline completed & social support \\
\hline s capturing & were significantly \\
\hline & associated with \\
\hline $\begin{array}{l}\text { factors, } \\
\text { y stress }\end{array}$ & $\begin{array}{l}\text { depression after } \\
\text { controlling for }\end{array}$ \\
\hline & ucation, \\
\hline $\begin{array}{l}\text { psychosocial } \\
\text { resources, and }\end{array}$ & $\begin{array}{l}\text { income, } \\
\text { employment and }\end{array}$ \\
\hline & past \\
\hline factors; & chemoth \\
\hline egression & Discrimination, \\
\hline usec & negative identity, \\
\hline $\begin{array}{l}\text { ass } \\
\text { bet }\end{array}$ & \\
\hline raphic anc & Icantly \\
\hline clini & iated with \\
\hline cteristics & anxi \\
\hline & and \\
\hline $\begin{array}{l}\text { associations } \\
\text { between minority }\end{array}$ & $\begin{array}{l}\text { anxiety were } \\
\text { correlated }(r=.4\end{array}$ \\
\hline stres & Outne \\
\hline hological & identity \\
\hline resc & were significantly \\
\hline & \\
\hline & $\begin{array}{l}\text { associated with } \\
\text { distress. }\end{array}$ \\
\hline correlations and & Resilience and \\
\hline & social support \\
\hline ographic and & were negatively \\
\hline cal factorc & associated with \\
\hline $\begin{array}{l}\text { assoclated wit } \\
\text { distress; struct }\end{array}$ & Discrimination \\
\hline & \\
\hline modeling tested & association $\mathrm{v}$ \\
\hline
\end{tabular}

Strengths: First study to demonstrate resilience as a positive resource for WSW to buffer the effects of discrimination on distress; use of validated scales (LGB Identity Scale [31], RS-14, ISELSF, HADS).

Limitations: Selfreport, crosssectional nature of study; lack of sociodemogaphic diversity in sample. 
effects on

distress;

statistically

significant indirect

effects interpreted

as mediation. distress mediated

by resilience.
Wheldon,
Roberts, \&

Boehmer

(2019) [32]
U.S.

Female breast

cancer survivors

stage 0 -III $(n=330$

lesbian, $n=525$

heterosexual)

Quantitative

Tested a

theoretical

framework to

explain

differences in

coping between

lesbian and

heterosexual

breast cancer

survivors; five

subscales from

the Mini-MAC

Scale used to

measure coping

with breast cancer

among women

post-treatment;

mediation

analysis used to

examine the

explanatory power

of life course

factors (e.g.,

parenting and

education) in

explicating the

association

between sexual

identity and

coping responses.
Lesbian women Strengths:

had less avoidant Replicates other coping strategies literature

and lower levels indicating

of anxious

preoccupation

than heterosexual

counterparts.

resilience among

lesbian breast

cancer survivors.

Limitations: Cross-

sectional study

with a non-random

sample that is

mostly white.

\section{Colorectal cancer (CRC)}

\begin{tabular}{|c|c|c|c|c|}
\hline $\begin{array}{l}\text { Baughman } \\
\text { et al. (2017) } \\
\text { [33] }\end{array}$ & U.S. & $\begin{array}{l}\text { Queer survivors } \\
\text { with a diagnosis } \\
\text { of stage III CRC } \\
(n=8)\end{array}$ & Qualitative & $\begin{array}{l}\text { Semi-structured } \\
\text { telephone } \\
\text { interviews }\end{array}$ \\
\hline
\end{tabular}

[33]

Participants
reported economic
challenges
associated with
insurance
coverage,
employment, and
housing as well as
social isolation.

Participants challenges associated with insurance employment, and social isolation.
Strengths: This is the only known study focusing on queer CRC

survivors; Sample was diverse in sex sexual orientation, and socioeconomic status. Limitations: Lack of racial/ethnic diversity in sample; lack of staging in CRC respondents.

\section{Prostate cancer ( $P r C)$.}

\section{Allensworth- U.S.}

Davies et al.

(2016) [34]
Gay men age 50+ with a diagnosis of PrC $(n=111)$

Quantitative

Cross-sectional national survey using multivariate generalized linear modeling with primary outcome as masculine self esteem.
Men who were comfortable disclosing their sexual orientation to their doctor had higher masculine self-esteem scores. Mental health was positively correlated with masculine selfesteem. This study distinguished experiences of gay PrC survivors from heterosexual
Strengths: use of several validated scales (SF-12, EIPC, PDRQ-9); control of confounding variables; diversity of the study population in terms of age, insurance type, employment status, and treatment protocol. Limitations: convenience sample; lack of 
counterparts in terms of stigma and resilience. racial/ethnic diversity of participants.

\begin{tabular}{|c|c|c|c|c|}
\hline $\begin{array}{l}\text { Capistrant } \\
\text { et al. (2016) } \\
\text { [35] }\end{array}$ & U.S. & $\begin{array}{l}\text { Gay and bisexual } \\
\text { men who had } \\
\text { been diagnosed } \\
\text { with PrC recruited } \\
\text { from a national } \\
\text { cancer support } \\
\text { group network } \\
(n=30)\end{array}$ & Qualitative & $\begin{array}{l}\text { One-on-one } \\
\text { interviews probed } \\
\text { for experiences } \\
\text { with providers; } \\
\text { health; sexual } \\
\text { functioning; } \\
\text { relationships; and } \\
\text { informational, } \\
\text { instrumental, and } \\
\text { emotional support } \\
\text { throughout } \\
\text { prostate cancer. }\end{array}$ \\
\hline
\end{tabular}

Single men in the study reported a need for independence; partnered men indicated varying levels of dependence on partners for support; many participants wished for more support options tailored for gay and bisexual men. In contrast to literature describing heterosexual prostate cancer survivors, most support for gay and bisexual men came from family and friends rather than partners.
Strengths: One of few studies of gay and bisexual prostate cancer survivors. Limitations: The sample was not very diverse: almost all participants were white, gay, and HIV-. There was not clear theoretical basis for the analysis.

\begin{tabular}{|c|c|c|c|c|c|c|}
\hline $\begin{array}{l}\text { Crangle, } \\
\text { Latini, \& } \\
\text { Hart (2017) } \\
{[36]}\end{array}$ & $\begin{array}{l}\text { U.S. and } \\
\text { Canada }\end{array}$ & $\begin{array}{l}\text { MSM who had } \\
\text { been diagnosed } \\
\text { with PrC within } \\
\text { the last } 4 \text { years } \\
(n=92)\end{array}$ & Quantitative & $\begin{array}{l}\text { Convenience } \\
\text { sample of MSM } \\
\text { recruited through } \\
\text { a variety of } \\
\text { methods; } \\
\text { demographic, } \\
\text { medical } \\
\text { information, and } \\
\text { measures of } \\
\text { attachment and } \\
\text { illness } \\
\text { intrusiveness were } \\
\text { collected; } \\
\text { mediation models } \\
\text { were tested using } \\
\text { bootstrapping to } \\
\text { examine each } \\
\text { attachment } \\
\text { dimension on } \\
\text { subscales of IIRS, } \\
\text { controlling for age } \\
\text { and days since } \\
\text { diagnosis. }\end{array}$ & $\begin{array}{l}\text { Younger age and } \\
\text { greater anxious } \\
\text { attachment were } \\
\text { associated with } \\
\text { greater illness } \\
\text { intrusiveness. } \\
\text { Greater anxious } \\
\text { attachment was } \\
\text { associated with } \\
\text { less comfort with } \\
\text { outness. Less } \\
\text { comfort with } \\
\text { being out to one's } \\
\text { provider mediated } \\
\text { the association } \\
\text { between greater } \\
\text { anxious } \\
\text { attachment and } \\
\text { more illness } \\
\text { intrusiveness. } \\
\text { This means that } \\
\text { comfort with } \\
\text { outness could } \\
\text { reduce illness } \\
\text { intrusiveness for } \\
\text { MSM with } \\
\text { anxious } \\
\text { attachment styles. }\end{array}$ & $\begin{array}{l}\text { Strengths: use of } \\
\text { previously } \\
\text { developed scales } \\
\text { (RQ; IIRS) and a } \\
\text { newly developed } \\
\text { Outness Inventory } \\
\text { that demonstrated } \\
\text { strong reliability } \\
\text { (subscales a }{ }^{3} .86 \text { ). } \\
\text { Limitations: Cross- } \\
\text { sectional design; } \\
\text { self-report data; } \\
\text { predominantly } \\
\text { white, highly } \\
\text { educated sample; } \\
\text { variable internal } \\
\text { reliability of the } \\
\text { RQ. }\end{array}$ \\
\hline $\begin{array}{l}\text { Hart et al. } \\
(2014) \text { [37] }\end{array}$ & $\begin{array}{l}\text { U.S. and } \\
\text { Canada }\end{array}$ & $\begin{array}{l}\text { SM who had been } \\
\text { diagnosed with } \\
\text { PrC within the last } \\
4 \text { years }(n=92)\end{array}$ & Quantitative & $\begin{array}{l}\text { Convenience } \\
\text { sample of MSM } \\
\text { recruited through } \\
\text { a variety of } \\
\text { methods; } \\
\text { Demographic, } \\
\text { medical } \\
\text { information, and } \\
\text { measures of QOL, } \\
\text { HRWOL, change in } \\
\text { sexual activity, } \\
\text { sexual side } \\
\text { effects, }\end{array}$ & $\begin{array}{l}\text { MSM reported } \\
\text { significantly } \\
\text { worse urinary and } \\
\text { bowel function, } \\
\text { greater bother of } \\
\text { lack of ejaculation } \\
\text { than heterosexual } \\
\text { peers from other } \\
\text { published studies, } \\
\text { lower satisfaction } \\
\text { with PrC care-but } \\
\text { overall health } \\
\text { status was }\end{array}$ & $\begin{array}{l}\text { Strengths: Use of } \\
\text { validated scales } \\
\text { (EPIC; SF-36; } \\
\text { MSHQ; CapSURE; } \\
\text { ILLS) and a newly } \\
\text { developed } \\
\text { Outness Inventory } \\
\text { that demonstrated } \\
\text { strong reliability. } \\
\text { Limitations: } \\
\text { Predominantly } \\
\text { white, educated, } \\
\text { and "out" self- }\end{array}$ \\
\hline
\end{tabular}


satisfaction with care, self-efficacy for symptom management, disease-specific anxiety, illness intrusiveness, and "outness level" collected; mean scores were calculated and compared to published population means in studies using the same scale, where possible; open-text responses reported descriptively. similar. MSM

reported

significantly

worse mental but

not worse

physical health

functioning than

heterosexual

peers. Nearly half

(49\%) of MSM

reported changes

to erectile function

and $40.2 \%$

indicated less

frequency of

sexual activity.

MSM reported

painful erections,

climacturia, low

libido, changes in

self-image, partner

struggling with

relationship

changes, and

significant

changes in sexual experiences due to

lack of

ejaculation. selected sample; cross-sectional design; variation in study design of comparison groups.

\begin{tabular}{|c|c|c|}
\hline $\begin{array}{l}\text { Hartman et } \\
\text { al. (2013) } \\
\text { [38] }\end{array}$ & Canada & $\begin{array}{l}\text { Homosexual } \\
\text { couples following } \\
\text { one partner's } \\
\text { radical } \\
\text { prostatectomydue } \\
\text { to PrC (n=6; i.e., } \\
\text { three couples) }\end{array}$ \\
\hline
\end{tabular}

Qualitative

Interpretative
phenomenological
analysis using
inductive coding.

Major themes included acknowledging, accommodating, and accepting sexual changes. Unlike research on heterosexuals, the role of open relationships was helpful in 2 of the 3 partners studied. These couples also benefited from communication (similar to heterosexual couples). For the third couple, sexual dysfunction was so significant that communication did not feel beneficial in helping with sexual health.

\begin{tabular}{|c|c|c|c|c|}
\hline $\begin{array}{l}\text { Lee, Breau, } \\
\text { \& Eapen } \\
(2013)[39]\end{array}$ & Canada & $\begin{array}{l}\text { MSM with PCa } \\
(n=15)\end{array}$ & Quantitative & $\begin{array}{l}\text { Pilot study } \\
\text { comparing post- } \\
\text { treatment QOL in } \\
\text { MSM who had } \\
\text { surgery to MSM } \\
\text { who had radiation } \\
\text { for treatment of } \\
\text { PCa. }\end{array}$ \\
\hline
\end{tabular}

While the sample size precluded statistical comparisons, the radiation group appeared to have fewer sexual side effects posttreatment in terms of retained ability for penetrative and receptive intercourse.
Strengths: This study provides a counternarrative to the dominant heterosexual assumptions about sexual health following radical prostatectomy Limitations: The study was exploratory with a small sample.
Strengths: Use of validated scales (EPIC, MSHQ). Limitations: Pilot study with small sample prevented statistical analysis; researcher-created sexual function survey not validated.

\begin{tabular}{|c|c|c|c|c|c|c|}
\hline $\begin{array}{l}\text { Lee et al. } \\
\text { (2015) [40] }\end{array}$ & Canada & $\begin{array}{l}\text { MSM with PCa } \\
(n=16)\end{array}$ & Qualitative & $\begin{array}{l}\text { MSM were } \\
\text { interviewed face- }\end{array}$ & $\begin{array}{l}\text { Themes from } \\
\text { semi-structured }\end{array}$ & $\begin{array}{l}\text { Strengths: The } \\
\text { first qualitative }\end{array}$ \\
\hline
\end{tabular}


to-face or via

video

conferencing and

asked about

sexual QOL after

PCa. Interviews

were recorded,

transcribed, and

analyzed. interviews

included sexual

dysfunction (e.g.

erectile, urinary,

ejaculation, and

orgasmic),

intimacy

challenges, and

lack of support for

cancer and

psychosocial

needs. Sexual

QOL and

relationship

confidence were

lower for those

with greater

sexual

dysfunction.

Coping was

challenged by lack

of support. study exploring the impact of PCa on MSM survivors' sexual experiences; rich data to develop a new QOL instrument specific to MSM PCa survivors.

Limitations:

Sociodemographic diversity not discussed.
Hoyt et al.

(2020) [41]
U.S.

(n)

Gay men who had Qualitative

been diagnosed

with $\operatorname{PrC}(\mathrm{n}=11)$

Focus groups
$(n=3)$ with gay
prostate cancer
survivors ( $n=11)$
using
conventional
content analysis.

Major challenges for participants included minority stress, intimacy/sexuality concerns, impact on life outlook, healthcare experiences, social support and the gay community, and intersectional identities.
Strengths: 2-3hour time for focus groups allowed for participant directed discussion; racial diversity in sample.

Limitations: Small sample size.

\begin{tabular}{|c|c|c|c|}
\hline $\begin{array}{l}\text { McConkey } \\
\text { \& Holborn } \\
\text { (2018) [42] }\end{array}$ & Ireland & $\begin{array}{l}\text { Gay men with } \\
\text { PCa }(n=8)\end{array}$ & Qualitative \\
\hline
\end{tabular}

In-depth

interviews based

on

phenomenology

were conducted

with gay $\mathrm{PCa}$

survivors:

interviews were recorded and transcribed; data was divided into "meaning units"; credibility and trustworthiness were bolstered by reflexivity, memoing, field notes of interviewee behaviors, and peer review of thematic descriptions from the data.
Three major themes that emerged included: 1) the experience of diagnosis and treatment, marked by shock at diagnosis, overwhelm during decision-making, sexual impacts of treatment; and degree of access to a nurse specialist; 2) experiences of health care service, including disclosure and communication with the care team; and 3) sources of support (e.g., family, friends), heteronormativity of support groups, and lack of gay community resources.
Strengths: First known study to explore gay $\mathrm{PCa}$ survivor experiences in Ireland.

Limitations: Lack of racial, national, and educational diversity in sample (important since $14-23 \%$ of the gay population in Ireland is foreign born).

\begin{tabular}{|c|c|c|c|c|c|c|}
\hline $\begin{array}{l}\text { Motofei et } \\
\text { al. (2011) } \\
\text { [43] }\end{array}$ & Romania & $\begin{array}{l}\text { Romanian PCa } \\
\text { survivors ( } n=17 \\
\text { heterosexual men, } \\
n=12 \text { gay men) }\end{array}$ & Quantitative & $\begin{array}{l}\text { Gay and } \\
\text { heterosexual PCa } \\
\text { survivors were } \\
\text { asked about }\end{array}$ & $\begin{array}{l}\text { Mean IIEF scores } \\
\text { were lower after } \\
\text { bicalutamide } \\
\text { exposure for the }\end{array}$ & $\begin{array}{l}\text { Strength: First } \\
\text { known study of } \\
\text { gay PCa cancer } \\
\text { survivors in }\end{array}$ \\
\hline
\end{tabular}


sexual functioning prior to and after starting

bicalutamide

monotherapy. A

2x2 factorial

ANOVA compared

heterosexual $v$.

gay and pre- $v$.

post-exposure to

bicalutamide. full group $(p<.001)$ with greater reductions in scores for gay $\mathrm{v}$. heterosexual survivors after exposure.
Romania; only study found to examine sexual impact of a drug by sexual orientation; use of validated scale (IIEF). Limitations: Small sample size; potential for recall bias; binary design does not account for bisexuality.

$\begin{array}{lll}\text { Polter et al. } & \text { U.S. } & \text { PCa survivors } \\ \text { (2019) [44] } & & \text { who participated } \\ & \text { in the RESTORE } \\ & \text { study ( } n=191) \\ & \text { including HIV+ } \\ & (n=24) \text { and HIV- } \\ & (n=167) \text { MSM }\end{array}$

Quantitative

Cross-sectional, online survey of MSM treated for PCa examined sexual function, bother, and HRQOL using MANOVA and multivariate linear regression to evaluate association of HIV status and HRQOL after controlling for demographic and sexual characteristics.
HIV+ status was associated with lower mean urinary, sexual, and bowel scores on the EPIC after controlling for demographic and sexual characteristics. HRQOL did not differ by HIV status.
Strengths: Use of validated scales (EPIC, SF-12). Limitations: Small number of HIV+ men in the sample; cross-sectional design; evidence of fraudulent responses (procedure used to omit 200 responses was not described).

$\begin{array}{lll}\text { Rosser et al. } & \text { U.S. } & \text { Gay and bisexual } \\ \text { (2016) [45] } & & \text { Qualitative }(n=19)\end{array}$

Rosser et al
(2016) [45]

men $(n=19)$
In-depth telephone Themes included interviews with gay and bisexual men who had radical prostatectomies.

shock at

diagnosis; depression; anxiety, grief, loss of sexual confidence; changes in sense of "maleness," gay/bisexual identity, sex-role identity; sex interest and partners; disclosure of cancer survivorship status; and changes to relationships including renegotiation of exclusivity with partners.
Strengths: One of few studies focused on gay and bisexual prostate cancer survivors.

Limitations: Small sample size.

\begin{tabular}{|c|c|c|}
\hline $\begin{array}{l}\text { Thomas et } \\
\text { al. (2013) } \\
\text { [46] }\end{array}$ & Australia & $\begin{array}{l}\text { Australian MSM } \\
\text { with a PCa } \\
\text { diagnosis withir } \\
\text { the last } 7 \text { years } \\
(n=10)\end{array}$ \\
\hline
\end{tabular}

\section{Qualitative}

An asynchronous, online focus group was hosted over 4 weeks with MSM PCa survivors discussing impact of PCa on their lives.

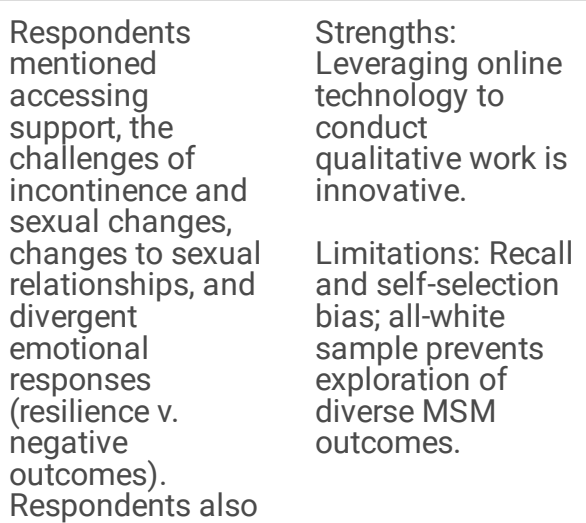


indicated that

general

practitioners were

more empathic

than their

urologists, and felt

their emotional

needs were not

adequately

addressed and

that interactions

with urologists

were often

distressing.

\begin{tabular}{|c|c|c|c|c|c|}
\hline $\begin{array}{l}\text { Thomas et } \\
\text { al. (2018) } \\
\text { [47] }\end{array}$ & Australia & $\begin{array}{l}\text { Australian PCa } \\
\text { survivors }(n=813)\end{array}$ & Quantitative & $\begin{array}{l}\text { An online survey } \\
\text { asked } \\
\text { respondents } \\
\text { about } \\
\text { demographics, } \\
\text { treatment } \\
\text { modality for PCa, } \\
\text { body image, self- } \\
\text { esteem, sexual } \\
\text { function and } \\
\text { urinary function; a } \\
\text { 2x2 ANcOVA was } \\
\text { conducted to } \\
\text { examine the main } \\
\text { effect of two } \\
\text { factors: sexual } \\
\text { orientation and } \\
\text { PCa diagnosis } \\
\text { over six } \\
\text { outcomes: self- } \\
\text { esteem, urinary } \\
\text { function, sexual } \\
\text { function, } \\
\text { appearance } \\
\text { evaluation, health } \\
\text { evaluation, and } \\
\text { health orientation; } \\
\text { differences in age } \\
\text { and Gleason score } \\
\text { were also } \\
\text { examined. }\end{array}$ & $\begin{array}{l}\text { Never-diagnosed } \\
\text { respondents were } \\
\text { statistically } \\
\text { significantly } \\
\text { younger than } \\
\text { cancer survivors. } \\
\text { Overall, gay } \\
\text { respondents had } \\
\text { statistically } \\
\text { significantly } \\
\text { higher age-- } \\
\text { adjusted self- } \\
\text { esteem scores } \\
\text { compared to } \\
\text { heterosexual } \\
\text { peers. PCa } \\
\text { survivors had } \\
\text { statistically } \\
\text { significantly } \\
\text { worse urinary and } \\
\text { sexual function } \\
\text { and health } \\
\text { orientation than } \\
\text { never- diagnosed } \\
\text { peers. No } \\
\text { statistically } \\
\text { significant } \\
\text { differences in } \\
\text { outcomes were } \\
\text { found between } \\
\text { gay and } \\
\text { heterosexual PCa } \\
\text { survivors, } \\
\text { although urinary } \\
\text { function } \\
\text { differences only } \\
\text { narrowly failed to } \\
\text { meet statistical } \\
\text { significance } \\
\text { (p=.054). }\end{array}$ \\
\hline
\end{tabular}

\begin{tabular}{|c|c|c|c|c|c|c|}
\hline $\begin{array}{l}\text { Torbit et al. } \\
(2015) \text { [48] }\end{array}$ & $\begin{array}{l}\text { U.S. and } \\
\text { Canada }\end{array}$ & $\begin{array}{l}\text { MSM who } \\
\text { received a PCa } \\
\text { diagnosis within } \\
\text { the prior } 4 \text { years } \\
(n=92)\end{array}$ & Quantitative & $\begin{array}{l}\text { A multiple } \\
\text { mediation design } \\
\text { was used to test } \\
\text { both self-efficacy } \\
\text { and satisfaction } \\
\text { with care on the } \\
\text { relationship } \\
\text { between physical } \\
\text { symptom severity } \\
\text { and FOR for PCa } \\
\text { survivors. }\end{array}$ & $\begin{array}{l}\text { Worse physical } \\
\text { symptoms were } \\
\text { associated with } \\
\text { greater FOR. Self- } \\
\text { efficacy and } \\
\text { satisfaction of } \\
\text { care mediated the } \\
\text { statistically } \\
\text { significant } \\
\text { relationship } \\
\text { between worse } \\
\text { bowl function, } \\
\text { worse hormone } \\
\text { function, and } \\
\text { worse sexual } \\
\text { function with FOR, } \\
\text { respectively. Self- } \\
\text { efficacy and } \\
\text { satisfaction did }\end{array}$ & $\begin{array}{l}\text { Strengths: Use of } \\
\text { a validated tool } \\
\text { (EPIC) and tools } \\
\text { from prior studies } \\
\text { to measure self- } \\
\text { efficacy and } \\
\text { satisfaction with } \\
\text { care. Limitations: } \\
\text { Mostly white, } \\
\text { educated, } \\
\text { partnered sample; } \\
\text { cross-sectional } \\
\text { design; self-report } \\
\text { data. }\end{array}$ \\
\hline
\end{tabular}


not mediate worse urinary function and FOR, but did explain $61 \%$ of the variance in the sample for that outcome.

\begin{tabular}{|c|c|c|c|c|c|}
\hline $\begin{array}{l}\text { Ussher et al. } \\
\text { (2016) [49] }\end{array}$ & Australia & $\begin{array}{l}\text { Australian PCa } \\
\text { survivors ( } \mathrm{n}=124 \\
\text { MSM, } n=225 \\
\text { heterosexual } \\
\text { men) }\end{array}$ & Quantitative & $\begin{array}{l}\text { Participants were } \\
\text { recruited through } \\
\text { urology and } \\
\text { primary care } \\
\text { practices, support } \\
\text { groups, SGM } \\
\text { community } \\
\text { groups, social } \\
\text { media, and cancer } \\
\text { research volunteer } \\
\text { databases; } \\
\text { multiple } \\
\text { regression and } \\
\text { independent } \\
\text { samples t-tests } \\
\text { assessed group } \\
\text { differences; } \\
\text { Pearson's } \\
\text { correlations } \\
\text { assessed } \\
\text { associations } \\
\text { between MSM } \\
\text { and heterosexual } \\
\text { samples; multiple } \\
\text { linear regression } \\
\text { was used to } \\
\text { identify } \\
\text { meaningful } \\
\text { predictor } \\
\text { variables for } \\
\text { HRQOL. }\end{array}$ & $\begin{array}{l}\text { MSM were } \\
\text { younger, less likely } \\
\text { to be partnered, } \\
\text { and more likely to } \\
\text { have casual sex } \\
\text { than heterosexual } \\
\text { peers in the } \\
\text { sample. MSM } \\
\text { reported worse } \\
\text { HRQOL, worse } \\
\text { masculine self- } \\
\text { esteem, lower } \\
\text { satisfaction with } \\
\text { care, higher } \\
\text { psychological and } \\
\text { cancer-related } \\
\text { distress, greater } \\
\text { ejaculation } \\
\text { concerns, higher } \\
\text { sexual } \\
\text { functioning, and } \\
\text { more sexual } \\
\text { confidence at } \\
\text { statistically } \\
\text { significant levels } \\
\text { compared to } \\
\text { heterosexual } \\
\text { peers. }\end{array}$ \\
\hline
\end{tabular}

Strengths: Use of validated tools (FACT-P, BSI-18, CSFQ-M, DSC EPIC, MAX-PC, $\mathrm{PCaQOL}$.

Limitations: Differences between MSM and heterosexual samples (e.g., age, ethnicity, employment status, relationship status, and treatments received).

$\begin{array}{lll}\begin{array}{ll}\text { Ussher et al. } \\ \text { (2017) [50] }\end{array} & \text { Australia, New } & \text { Australian MSM } \\ & \text { Zealand, U.K., } & \text { PCa survivors } \\ & \text { U.S. } & (n=124) \text { and their } \\ & & \text { partners }(n=21) ; \\ & \text { subset } \\ & \text { interviewed }(n=46 \\ & \text { survivors, } n=7 \\ & \text { partners) }\end{array}$

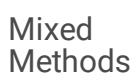

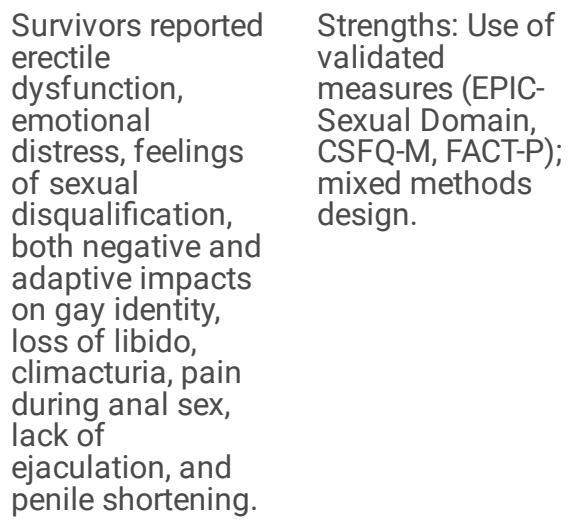

\begin{tabular}{|c|c|c|c|c|c|c|}
\hline $\begin{array}{l}\text { Wassersug } \\
\text { et al. (2013) } \\
\text { [51] }\end{array}$ & $\begin{array}{l}\text { International: } \\
\text { Primarily U.S., } \\
\text { Australia, } \\
\text { Canada, and } \\
\text { U.K. }\end{array}$ & $\begin{array}{l}\text { Men }(n=556) \\
\text { from } 17 \text { countries } \\
\text { with a diagnosis } \\
\text { of PCa ( } n=460 \\
\text { heterosexual men } \\
\text { and } n=96 \text { MSM) }\end{array}$ & Quantitative & $\begin{array}{l}\text { Logistic } \\
\text { regression and } \\
\text { Wald tests } \\
\text { assessed } \\
\text { outcomes } \\
\text { including sexual } \\
\text { health, urinary } \\
\text { incontinence, and } \\
\text { depression. }\end{array}$ & $\begin{array}{l}\text { No between group } \\
\text { differences were } \\
\text { found for urinary } \\
\text { incontinence or } \\
\text { erectile } \\
\text { dysfunction; } \\
\text { however, MSM } \\
\text { were more } \\
\text { bothered by }\end{array}$ & $\begin{array}{l}\text { Strengths: } \\
\text { International } \\
\text { reach, adaptation } \\
\text { of validated scale } \\
\text { (EPIC). } \\
\text { Limitations: } \\
\text { Sample is largely } \\
\text { affluent with }\end{array}$ \\
\hline
\end{tabular}


sexual impacts of

$\mathrm{PCa}$ than

heterosexual

peers. access to the internet.
Wright et al. U.S. and

(2019) [52] Canada
MSM ( $n=189)$

with a diagnosis

of PCa recruited

from Malecare, an

online cancer

support

organization

\begin{tabular}{|c|c|}
\hline Quantitative & $\begin{array}{l}\text { Linear regression } \\
\text { was used to } \\
\text { compare } \\
\text { participants with } \\
\text { cats only, dogs } \\
\text { only, both cats } \\
\text { and dogs, or no } \\
\text { pets on SF-12 } \\
\text { mental and } \\
\text { physical } \\
\text { component } \\
\text { scores. }\end{array}$ \\
\hline
\end{tabular}

Participants with pets had lower mental health scores than nonpet owners. Cat owners had better physical health than other groups.
Strengths: First study to look at companion animal ownership association with mental and physical wellbeing; use of validated scale (SF-12).

Limitations:

Convenience sample; crosssectional design; inability to determine directionality of association; no heterosexual control group.

\section{Multiple cancers}

$\begin{array}{lll}\text { Boehmer et } & \text { U.S. (California) } & \text { CHIS respondents } \\ \text { al. (2011) } & \text { ages } 18-70 \\ \text { [53] } & \text { (n=122,345 CHIS } \\ & \text { respondents, } \\ & n=10,942 \\ & \text { survivors) }\end{array}$

Pooled data from CHIS 2001, 2003, 2005 using logistic regression; primary outcomes were prevalence of cancer and selfreported health.*
WSW had ${ }^{3} 2.0$ odds of fair/poor health compared to heterosexual counterparts with greater risk for racial minorities and older women; greater prevalence and younger diagnosis of cancer were reported by MSM compared to heterosexual counterparts but self-reported health was not different for MSM.
Strengths: Large, population-based sample (CHIS); first known study to report prevalence of cancer and selfreported health of cancer survivors by sexual orientation. Limitations: Data collected only from one state; self-reported nature of the data.

\begin{tabular}{|c|c|c|c|c|}
\hline $\begin{array}{l}\text { Bryson et al. } \\
(2018) \text { [54] }\end{array}$ & Canada & $\begin{array}{l}\text { SGM breast and } \\
\text { gynecological } \\
\text { cancer survivors } \\
(n=81)\end{array}$ & Qualitative & $\begin{array}{l}\text { Purposive } \\
\text { sampling used to } \\
\text { recruit diverse } \\
\text { sample of SGM } \\
\text { breast cancer } \\
\text { survivors across } \\
\text { Canada; semi- } \\
\text { structured } \\
\text { interviews } \\
\text { conducted to } \\
\text { explore patient } \\
\text { experiences of } \\
\text { care, health } \\
\text { outcomes and } \\
\text { decision-making. }\end{array}$ \\
\hline
\end{tabular}

This study reported on perceptions of how intersectional identity influenced feelings of safety and interactions with health care providers. It provides evidence that cisnormative systems negatively shaped care experiences for genderqueer people. Relevant to the present review outcomes reported were: physical impacts of cancer treatment that resulted in altered experiences of gender in society; lack of preparation or hormonal

\author{
Strengths: \\ Diversity of \\ sample; rich \\ exploration of \\ narratives; large \\ sample; one of \\ two known studies \\ of genderqueer \\ cancer survivors \\ sharing their \\ experiences in \\ their own words. \\ Limitations: No \\ notable \\ limitations.
}




\begin{tabular}{|c|c|c|c|c|c|c|}
\hline & & & & & $\begin{array}{l}\text { treatment for } \\
\text { surgery-induced } \\
\text { menopause; and } \\
\text { mental health } \\
\text { effects associated } \\
\text { with lack of } \\
\text { hormonal } \\
\text { treatment. }\end{array}$ & \\
\hline $\begin{array}{l}\text { Kamen et } \\
\text { al. (2014) } \\
\text { [55] }\end{array}$ & U.S. & $\begin{array}{l}\text { Men who reported } \\
\text { sexual orientation } \\
\text { in the BRFSS in } \\
2009 \text { from } \\
\text { Arizona, } \\
\text { California, } \\
\text { Massachusetts, } \\
\text { Ohio, and } \\
\text { Wisconsin } \\
\text { (n=14,354) }\end{array}$ & Quantitative & $\begin{array}{l}\text { The complex } \\
\text { sampling } \\
\text { procedure in SPSS } \\
\text { (v. 20.0) weighted } \\
\text { the sample based } \\
\text { on demographic } \\
\text { variables and } \\
\text { state of residence; } \\
\text { statistically } \\
\text { significant } \\
\text { between-group } \\
\text { differences were } \\
\text { used as co- } \\
\text { variates for a } \\
\text { logistic regression } \\
\text { and t-tests } \\
\text { examining } \\
\text { outcomes.* }\end{array}$ & $\begin{array}{l}\text { Gay men were } \\
82 \% \text { more likely to } \\
\text { report a cancer } \\
\text { diagnosis }(p<.05) \\
\text { and were more } \\
\text { likely to report less } \\
\text { exercise, more } \\
\text { distress, and } \\
\text { greater alcohol } \\
\text { and/or tobacco } \\
\text { use. These health } \\
\text { behaviors were } \\
\text { shown to continue } \\
\text { after a cancer } \\
\text { diagnosis for gay } \\
\text { men. }\end{array}$ & $\begin{array}{l}\text { Strengths: } \\
\text { Population-based } \\
\text { sample from five } \\
\text { states; first study } \\
\text { to examine cancer } \\
\text { disparities among } \\
\text { gay men. } \\
\text { Limitations: Cross- } \\
\text { sectional design } \\
\text { of BRFSS; } \\
\text { potential lack of } \\
\text { disclosure of } \\
\text { sexual orientation } \\
\text { among } \\
\text { respondents. }\end{array}$ \\
\hline $\begin{array}{l}\text { Kamen et } \\
\text { al. (2015) } \\
\text { [56] }\end{array}$ & U.S. & $\begin{array}{l}\text { LiveStrong survey } \\
\text { respondents: } \\
n=207 \text { SGM, } \\
n=4899 \\
\text { heterosexual } \\
\text { cancer survivors } \\
\text { in } 2010\end{array}$ & Quantitative & $\begin{array}{l}\text { Propensity } \\
\text { matched cancer } \\
\text { survivors ( } n=621 \\
\text { heterosexual v. } \\
207 \text { LGBT } \\
\text { survivors) } \\
\text { assessed for } \\
\text { distressed, } \\
\text { difficulties with } \\
\text { social } \\
\text { relationships, } \\
\text { fatigue and } \\
\text { energy; symptoms } \\
\text { assessed through } \\
\text { dichotomous } \\
\text { yes/no items and } \\
\text { analyzed using } \\
\text { Poisson } \\
\text { regression; } \\
\text { subgroup } \\
\text { analyses by sex } \\
\text { conducted. }\end{array}$ & $\begin{array}{l}\text { SGM men } \\
\text { reported greater } \\
\text { depression and } \\
\text { more relationship } \\
\text { difficulties } \\
\text { compared to } \\
\text { heterosexual } \\
\text { counterparts. } \\
\text { SGM women did } \\
\text { not have } \\
\text { differences } \\
\text { compared to } \\
\text { heterosexual } \\
\text { peers. }\end{array}$ & $\begin{array}{l}\text { Strengths: First- } \\
\text { known study to } \\
\text { examine } \\
\text { psychological } \\
\text { distress of sexual } \\
\text { minority cancer } \\
\text { survivors. } \\
\text { Limitations: Cross- } \\
\text { sectional design } \\
\text { of the study. }\end{array}$ \\
\hline $\begin{array}{l}\text { Kamen et } \\
\text { al. (2015) } \\
\text { [57] }\end{array}$ & U.S. & $\begin{array}{l}291 \text { SGM cancer } \\
\text { survivors }(n=159 \\
\text { MSM, } n=123 \\
\text { WSW, } n=7 \\
\text { transgender men, } \\
n=2 \text { transgender } \\
\text { women) }\end{array}$ & Quantitative & $\begin{array}{l}\text { Participant } \\
\text { demographics, } \\
\text { cancer diagnosis, } \\
\text { experiences of } \\
\text { care, support- } \\
\text { related factors, } \\
\text { and self-rated } \\
\text { health were } \\
\text { assessed through } \\
\text { a researcher- } \\
\text { developed survey; } \\
\text { descriptive data } \\
\text { reported; logistic } \\
\text { regression used to } \\
\text { compare } \\
\text { outcomes. }\end{array}$ & $\begin{array}{l}\text { Parental support } \\
\text { was the strongest } \\
\text { single factor } \\
\text { associated with } \\
\text { good health } \\
\text { followed by } \\
\text { having a partner } \\
\text { present during } \\
\text { cancer diagnosis. }\end{array}$ & $\begin{array}{l}\text { Strength: One of } \\
\text { the largest studies } \\
\text { of SGM cancer } \\
\text { survivors at the } \\
\text { time of } \\
\text { publication. } \\
\text { Limitations: } \\
\text { Researcher- } \\
\text { created survey } \\
\text { that has not been } \\
\text { validated; self- } \\
\text { report data; cross- } \\
\text { sectional design; } \\
\text { self-selection bias; } \\
\text { recall bias of } \\
\text { support and } \\
\text { comparison of } \\
\text { support at } \\
\text { diagnosis with } \\
\text { present self- } \\
\text { reported health. }\end{array}$ \\
\hline
\end{tabular}




\begin{tabular}{|c|c|c|c|c|}
\hline $\begin{array}{l}\text { Kamen et } \\
\text { al. }(2016) \\
\text { [58] }\end{array}$ & U.S. & $\begin{array}{l}\text { Queer }(n=10) \text { and } \\
\text { heterosexual } \\
(n=12) \text { cancer } \\
\text { survivors }\end{array}$ & Quantitative & $\begin{array}{l}\text { Randomized } \\
\text { controlled trial of } \\
\text { a 6-week exercise } \\
\text { intervention } \\
\text { comparing } \\
\text { survivor-only v. } \\
\text { survivor-caregiver } \\
\text { dyad using } \\
\text { independent } \\
\text { samples t-tests. }\end{array}$ \\
\hline
\end{tabular}

At baseline, queer survivors reported greater depression $(p=.01)$ and fewer steps walked $(p=.03)$ compared to heterosexual counterparts.

Post-intervention, there were no differences between queer $\mathrm{v}$. heterosexual survivors, but survivors with partner support had a significantly greater reduction in depressive symptoms compared to the survivor-only group.
Strengths: One of very few interventional studies to improve QOL of queer cancer survivors; use of validated scales (CES-D, STAI, DSQ). Limitations: Small sample size.
Lisy et al. (2019) [59]
Australian cancer survivors $(n=2115)$

Cancer survivors
diagnosed
between $2009-$
2013 were
identified through
the Victorian
Cancer Registry
and asked to
complete a survey
about
demographics,
QOL, social
difficulties, and
information
needs; descriptive
data reported as
well as between-
group differences
(SGM v.
heterosexual).

heterosexual).
Of the 2115

Australian cancer survivors who responded to the survey, $33(1.6 \%)$ disclosed SGM status. SGM survivors had significantly fewer financial, support, and communication challenges posttreatment but greater challenges with diet and lifestyle than heterosexual peers. SGM survivors were more likely to report anxiety/ depression and body image challenges, but not at a statistically significant level.
Strengths: First population-based survey of SGM cancer survivors in Australia; use of some (unspecified) validated

measures.

Limitations:

Questionnaires were not validated; small SGM sample; sexual orientation was not decoupled from gender identity.

\begin{tabular}{|c|c|c|}
\hline $\begin{array}{l}\text { Matthews et } \\
\text { al. (2016) } \\
\text { [60] }\end{array}$ & U.S. & $\begin{array}{l}\text { SGM cancer } \\
\text { survivors }(n=175\end{array}$ \\
\hline
\end{tabular}

Quantitative

$$
\text { throur }
$$

\section{were}

through

organizations to

take an 82-item

online survey

asking about

demographics,

cancer type,

comorbid

conditions, health

behaviors, and

QOL; descriptive

statistics

summarized

demographics;

multivariable

models were

created to explore

associations with

physical and
Lower physical

QOL scores were associated with

older age at diagnosis, breast or gynecological cancer, medical co-morbidities, overweight or obesity, and cancer recurrence $(p<.05)$. Lower mental QOL scores were associated with younger age at diagnosis, lack of physical activity, FOR, lower levels of social and emotional support, and

Strengths: Use of
a validated QOL
measure (SF-12);
diversity of type
and stage of
cancer as well as
geography
distribution across
U.S. Limitations:
Cross-sectional,
convenience
sample; limited
racial/ethnic
diversity in
sample; no
comparison group.


mental subscales of the SF-12. participation in therapy/support groups $(p<.05)$.

Abbreviations: aOR=adjusted Odds Ratio; DCIS=Ductal Carcinoma In Situ, BrC=Breast Cancer, CRC=Colorectal Cancer, FOR=Fear of Recurrence, $\mathrm{PrC}=$ Prostate Cancer, $\mathrm{HRQOL}=$ Health Related Quality of Life, MSM=Men who have Sex with Men, SGM=Sexual and Gender Minorities, QOL=Quality of Life, WSW=Sexual Minority Women

*Appropriate tests were conducted to compare demographic and clinical characteristics between groups.

\section{Breast cancer survivorship}

The majority of studies found on SGM people with a history of cancer focused on breast cancer survivors, mostly comparing lesbian survivors to heterosexual counterparts. Half of the studies on breast cancer were quantitative and analyzed a variety of outcomes from the same two cohorts or subsets of those cohorts [11-13,15-18,21] and [15,19,20,22,24]. Given that half of the analyses were conducted in the same two samples of women, extrapolating findings from these studies on SGM with a history of breast cancer should be done with caution. Nevertheless, studies from these two cohorts combined with additional qualitative studies and one mixed methods study yielded important insights.

Participants studied were mostly white, educated, and employed. Women who have sex with women (WSW, a term used to be inclusive of lesbian, bisexual, and queer women and women who do not identify in these ways but partner with women) and heterosexual peers had similar quality of life (QOL) $[12,27]$ with a few exceptions. WSW with less financial means and those who experienced greater discrimination were more likely to have poorer physical health and increased anxiety and depression [12,13]. WSW also reported greater stress [28]. In one study, discrimination was associated with anxiety, but resilience and social support buffered this association [30]. WSW in these studies and their caregivers also showed greater dyadic effects on quality of life compared to heterosexual couples [24].

WSW reported more adaptive coping and improved health behaviors in response to a cancer diagnosis. After cancer diagnoses, WSW with $\mathrm{BMI}$ greater than 25 were more likely to lose weight compared with heterosexual counterparts, eliminating a statistically significant prediagnosis difference [11]. WSW reported less avoidant coping and anxious preoccupation than heterosexual peers [16,32]. For WSW, having a partner was associated with better sexual function, greater sexual desire, better mental and physical health, and less fear of recurrence compared to heterosexual counterparts [15-17,19,21]. In addition, WSW reported being less focused on body image, suffered fewer identity issues due to breast cancer and chose not to have reconstruction more often than heterosexual peers $[14,25,54]$. However, WSW reported more challenges with access to care [23] and experienced more physical complications related to mastectomy and radiation than heterosexual peers [18]. Counter to other studies, one study demonstrated an association between degree of "outness" (defined in the study as the number of relationships in which people were open about their identity) and higher distress [30], which may suggest increased experiences of stigmatization when people were open about their identities. While WSW did not perceive they were treated differently based on sexual orientation, $39 \%$ of WSW in one study said they were assumed to be heterosexual by their health care team [26]. Whether level of outness is linked to discriminatory experiences has not been explored. Overall, WSW displayed more resilient behaviors than heterosexual peers, though one study indicated there were no between-group differences in resilience based on sexual practices (WSW vs. heterosexual women) [10].

\section{Prostate cancer survivorship}

Studies on people with a history of prostate cancer primarily focused on genitourinary and relationship changes for men who have sex with men (MSM). MSM reported more genitourinary challenges than heterosexual peers, including worse urinary and bowel function, lack of ejaculation, changes to erectile function, climacturia, pain during anal sex, penile shortening, loss of libido, and less frequency of sexual activity [37,50,51]. MSM with HIV reported more significant detrimental effects of treatment than MSM without HIV [44]. One study showed that MSM had greater sexual dysfunction after bicalutamide monotherapy compared to heterosexual peers [43].

In qualitative studies, people with a history of prostate cancer reported fearing rejection and sexual abstinence after treatment: "Afterward I felt like I would never find another partner again and there was a depression" [35]. Among MSM who were dating or seeking casual sex, 
disclosure was seen as a challenge: "A lot of people hit on me, but I just dread that part in the conversation where I have to go, 'Well, just so you know, I'm a survivor of prostate cancer and there's never going to be any cum" [45]. Erectile dysfunction led to break-ups in some cases: "For a month or so it was going really nicely, but about a month in he stopped in the middle of sex one night and he said, 'I'm sorry, you're just not hard enough for me.' I was really upset because I was developing feelings for him" [45]. Loss of spontaneity was another noted adjustment:

Everything has to be planned ahead of time. How much are you drinking? How much salt did you take? Did you take Cialis? If you're on a date, you may want to have 100 milligram Viagra in your pocket. If you have any chance of going home with somebody, if you want to leave and do that, you can't drink a lot beforehand because you don't' want to pee in the guy's bed. All the stuff I never used to think of, ever. It was just wham, bam, thank you, man. You were much more free. Now, all the spontaneity is gone, which is a shame [45].

Several studies reported changes to MSM survivors' sense of identity as gay men, resulting in changes to relationships and worse mental health $[37,40,45,50]$. In one qualitative study, MSM describe erectile dysfunction as a persistent problem that is paramount to being "sexually inferior" or "leading to a sense of 'disqualification' of the sexual experience" [50]. Sexual changes were reported to adversely affect the mental health and identities of MSM. In Ussher et al.'s [50] study, a gay interviewee reported that erectile dysfunction was "the most horrific thing that I've ever been through psychologically." Another respondent indicated decisional regret, preferring to "take my risks with the cancer" if he could go back in time. One MSM interviewee explained his loss of libido as "a profound change in identity" and another said he felt "outside the sexual community" after the change in his sexual function [50]. Two qualitative studies found that renegotiation of exclusivity was one strategy that couples used to cope with physical symptoms and reduced sexual interest of the survivor. Specifically, survivors in this study encouraged partners to obtain sexual satisfaction outside of their relationship [38,45]. In contrast, some MSM reported more profound intimacy with their partner $[45,50]$ after cancer diagnosis and treatment.

Several studies demonstrated benefits of MSM's disclosure of sexual identity to their providers. In one study, MSM who were comfortable disclosing their sexual orientation had greater masculine self-esteem scores, which was linked to greater mental health [34]. Another study demonstrated reduced anxiety and less illness intrusiveness for MSM who had shared their sexual orientation with providers [36].

Studies also highlighted lack of resources and support tailored for MSM [42,46]. In Ussher et al.'s qualitative study [50], one MSM respondent summarized the issue like this: "Most health care professionals and others working in the prostate cancer field have no understanding of the different ways that prostate cancer can affect gay and bisexual men. Not just sexually, but in the non-sexual side of relationships. It's as though we're invisible." Other MSM described discomfort with a support group that was mostly attended by heterosexual people: "It's horrifying because there's this old man talking about sex with the wife. They don't want to hear about my problem. I didn't want to hear about theirs. It didn't work for me" [35]. In the same study, single MSM expressed the need to be extremely independent and not seek out support: "I was alone to recover... I didn't really want a lot of company. I mean, I'm walking around the house with a catheter tube sticking out of me, it wasn't really the time" [35]. Other participants noted that they did not want to bother their friends or chose to hire staff to help them rather than seek help from their friends [35].

\section{Transgender cancer survivorship}

Only four studies included transgender and/or genderqueer respondents [25,54,57,59]. Bryson et al. [54] found that intersectional identities impacted the experiences of transgender cancer survivors. Brown and McElroy [25] described health care providers "gender policing" when genderqueer patients made the decision to "go flat" and declined breast reconstruction. These experiences and treatment choices were associated with mixed physical and emotional outcomes. Participants reported being unprepared for early menopause and mental health impacts of hysterectomy. Kamen et al. [57] and Lisy et al. [59] included transgender respondents in their study, but the former did not stratify outcomes specific to transgender respondents, and the latter did not decouple gender identity from sexual orientation.

\section{Critical appraisal}

Most studies were either 1) secondary analyses of state-level data where data were available on sexual orientation and gender identity in population surveys or 2) cross-sectional surveys of survivors that could be subject to recall, self-selection, and social desirability bias. Only one study assessed the impact of a therapeutic drug on survivor outcomes [43]. The study was based on binary assumptions about sex and sexual orientation. However, it is singular in demonstrating hormone-based differences in response to cancer pharmacotherapies. A strength among many studies was use of validated measures, although sometimes these had to be adapted to be responsive to the experiences of SGM people. Table 3 catalogs measures used in the included studies. 
Summary of Validated Scales used in SGM Survivorship Research.

\begin{tabular}{|c|c|c|}
\hline Abbreviation & $\underline{\text { Scale }}$ & $\underline{\text { Reference }}$ \\
\hline BFS & Benefit Finding Scale & Antoni et al. (2001) [61] \\
\hline \multirow[t]{2}{*}{ BITS } & Breast Impact of Treatment Scale & Frierson, Thiel, \& Anderson (2006) [62] \\
\hline & Brief Symptom Inventory-18 & Derogatis \& Melisaratos (1983) [63] \\
\hline \multirow[t]{2}{*}{ BSS } & Berlin Social Support Scale & Schulz \& Schwarzer (2003) [64] \\
\hline & Key & \\
\hline CapSURE & Cancer of the Prostate Strategic Urologic Research Endeavor & Lubeck et al. (1996) [65] \\
\hline CES-D & Center for Epidemiological Studies Depression Scale & Radloff (1977) [66] \\
\hline \multirow[t]{2}{*}{ CHIS } & California Health Interview Survey & UCLA Center for Health Policy Research (2012) [67] \\
\hline & & Keller, McGarvey, \& Clayton (2006) [68] \\
\hline \multirow[t]{2}{*}{ DAS } & Dyadic Assessment Scale & Spanier (1976) [69] \\
\hline & & Clark et al. (2003) [70] \\
\hline DSQ & Dyadic Support Questionnaire & Vinokur \& Vanryn (1993) [71] \\
\hline EPIC & Expanded Prostate Cancer Index Composite & Wei et al., (2000) [72] \\
\hline FSFI & Female Sexual Function Index & Rosen et al., (2000) [74] \\
\hline HADS & Hospital Anxiety and Depression Scale & Zigmond \& Snaith (1983) [75] \\
\hline IIEF & International Index of Erectile Function & Rosen et al. (1997) [76] \\
\hline IIRS & Illness Intrusiveness Ratings Scale & Devins et al. (2001) [77] \\
\hline ISEL-SF & Interpersonal Support Evaluation List & Cohen et al. (1983) [78] \\
\hline Mini-MAC & Mini-Mental Adjustment to Cancer Scale & Watson et al. (1994) [79] \\
\hline QLQ-BR23 & EORTC Quality of Life Scale & Aaronson et al. (1993) [80] \\
\hline & Memorial Anxiety Scale for Prostate Cancer & Roth et al. (2003) [81] \\
\hline
\end{tabular}




\begin{tabular}{|c|c|c|}
\hline MBSRQ & Multidimensional Body-Self Relations Questionnaire & Cash (2000) [82] \\
\hline MSHQ & Male Sexual Health Questionnaire Short Form & Rosen et al. (2007) [83] \\
\hline MSPSS & Multidimensional Scale of Perceived Social Support & Zimet et al., (1988) [84] \\
\hline NHANES & National Health and Nutrition Examination Survey & Centers for Disease Control and Prevention (n.d.) [85] \\
\hline PCaQOL & Prostate Cancer-Related Quality of Life Scales & Clark et al. (2003) [70] \\
\hline PSS & Perceived Stress Scale & Cohen \& Wills (1985) [86] \\
\hline QOL-CSV & Quality of Life-Cancer Survivors & Ferrell, Hassey, \& Dow (1997) [87] \\
\hline RS-14 & Resilience Scale & Wagnild \& Young, (1993) [88] \\
\hline $\mathrm{RQ}$ & Relationship Questionnaire & Bartholomew \& Hororwitz, (1991) [89] \\
\hline SF-12 & Medical Outcomes Short Form-12 & Ware, Kosinski, \& Keller (1996) [90] \\
\hline SF-36 & Medical Outcomes Short Form 36 & Ware, Kosinski, \& Keller (1994) [91] \\
\hline STAI & State-Trait Anxiety Inventory & Spielberger, Gorsuch, \& Lushene (1968) [92] \\
\hline TPS & Trust in Physician Scale & Anderson \& Dedrick (1990) [93] \\
\hline
\end{tabular}

\section{Discussion}

\section{Differences among SGM populations}

Several studies that synthesized outcomes for people with a history of various cancers indicated worse physical outcomes for SGM compared to heterosexual, cisgender counterparts [29]. However, studies identified no mental health differences between WSW with cancer compared to heterosexual peers. In contrast, a number of studies demonstrated poorer mental health and increased relationship difficulties for MSM with cancer compared to heterosexual peers [56]. In two separate studies, WSW reported lower fear of recurrence while MSM reported greater fear of recurrence compared to heterosexual counterparts [21,48]. In other studies, MSM were also less likely to be partnered than heterosexual people in contrast to WSW, who were more likely to be partnered $[17,49]$. Partner support appeared to buffer negative effects for WSW [14,16,21], and partner support was associated with greater reduction in depression [57,58]. This buffering effect of partnership was not necessarily true for MSM [37]. The heightened dyadic effect of patient-caregiver quality of life shown in [24] highlights the importance of providers including WSW caregivers in cancer treatment discussions.

\section{Gaps in research}


Since the National Academies 2011 report on SGM health, more studies have been published which examine patient-reported outcomes of SGM people with a history of breast and prostate cancers. However, studies exploring the needs and outcomes of sexual minorities with other cancers as well as studies documenting and addressing the needs of gender minorities are severely limited. Only one study focused on people with a history of colorectal cancer. This study reported financial challenges of queer colorectal cancer survivors; however, there was no comparison group and no other studies with which to compare the sample. A few studies examined outcomes of people diagnosed with multiple cancers, but overall, more research on people surviving a variety of types of cancer is needed to understand differences in health-related outcomes for SGM survivors.

A critical gap exists in studies focusing on transgender, genderqueer, gender diverse and intersex patient outcomes. Only four studies mentioned transgender patients $[25,54,57,59]$. Of these, one study mentioned the term "intersex," yet no intersex people were actually included in the study; in addition, sexual orientation was not reported separately from gender identity, conflating multiple constructs [59]. Of note, intersex people often refer to themselves as female or male rather than intersex. Therefore, intersex individuals may be overlooked within some studies under binary sex categories when intersex status is not assessed.

Only one study was found that focused on AYA people with a history of cancer. This study found that SGM survivors were less concerned with the possibility of infertility and more open to being non-biological parents than heterosexual peers. However, this one qualitative study cannot be assumed to be generalizable. More work on AYA cancer survivorship that stratifies experiences and outcomes based on sexual orientation and gender identity is needed.

A strength of many of the studies was the use of validated measures. A list of measures is provided in Table 3 for reference. In some cases, measures used were constructed for heterosexual people and were not relevant to SGM populations. This was particularly true of measures focused on sexual function and outcomes. This major limitation of existing measures led researchers to sometimes create or adapt instruments for their studies. Validation of measures focused on SGM sexual outcomes is needed to ensure rigor and reliability of research and to allow for comparisons across studies of SGM survivors.

Finally, only one study was interventional. Kamen et al., [58] found a dyadic exercise intervention for partners to be more effective in reducing depression than a survivor-only intervention. Interventional research to address poorer physical health among lesbian breast cancer survivors and greater sexual challenges for MSM with prostate cancer are needed. Interventional research that provides early and clear information on fertility preservation is also needed for AYA and other survivors regardless of sexual orientation or gender identity.

\section{Limitations and strengths of this study}

This study was limited to articles published in English through February 2020 focused on SGM people with a history of cancer that reported a health-related outcome. The language limitation was due to lack of funding to translate non-English papers for the review. The study did not include studies that focused on experiences of care (such as patient satisfaction) or social support unless at least one health-related patient-reported outcome was an endpoint. By delimiting the literature in this way, important patient experiences are not summarized in this review. This study also did not include cancer prevention or screening studies or provider training interventions to address quality of care for SGM patients, since these studies do not focus on post-therapeutic health outcomes for patients. For a recent review that includes patient experiences and quality of care, see Kent et al. [94]. A major strength of this review is its comprehensiveness in summarizing SGM survivorship research to date due to the use of established scoping review methods $[7,8]$ and systematic searches of four databases.

\section{Conclusions}

This study summarized important between-group differences among SGM and heterosexual, cisgender counterparts. This review found clear differences in perspectives and health outcomes between WSW and MSM. Thus, researchers should take care to not conflate WSW and MSM when conducting analyses. Gender minority people have been understudied and expanding research in this area will be important to the creation of interventions to improve post-treatment experiences of gender minority people with a history of cancer. Sexual orientation, gender identity, chromosomes, hormone balance, and physical anatomy are separate constructs that should not be conflated. Finally, attention to intersectionality within SGM populations is critical as people with multiple intersecting aspects of their identity may have drastically different needs, experiences, and outcomes than those of SGM people who identify with only one marginalized population.

It is paramount that anatomy (including intersex status), sexual orientation, and gender identity be documented in Electronic Health Records and population-based surveys. Until these important fields are systematically captured by clinicians and researchers, SGM research will continue to be restricted to small sample sizes that are not powered to detect subgroup differences. Studies focused on heterosexual, cisgender populations will need to be replicated in convenience samples of SGM patients, which is poor stewardship of 
research funding dollars: Adding sexual orientation, gender identity, and intersex questions to all studies would be more efficient and provide more robust data to inform clinical care.

Finally, a shift to anatomy- and gender-based medicine that accounts for intersectionality is critical to effectively address the needs of SGM people with a cancer diagnosis. Clinicians must be trained on how to tailor medical management based on sexual orientation, gender identity, sexual practices, hormone levels, and physical anatomy rather than by monolithic, binary gender markers. Distinctions between sexual orientation and gender identity in research; structured data collection; and clinician training are critical for evidence-based, quality cancer care to improve health outcomes for SGM people. Furthermore, important cultural distinctions within groups that share sexual orientation, gender identity, and/or intersex categories may yield additional insights regarding within-group differences. Accounting for the diversity of lived experiences of SGM people in research design and analysis will help cancer care better address the needs of diverse populations. In sum, a growing literature describes patient-reported health outcomes of SGM people with a history of cancer, but without systematic registries and/or population-based data collection, data will continue to suffer substantial limitations, thereby reducing utility for clinical practice.

\section{Abbreviations}

AYA Adolescents and Young Adults

BMI Body Mass Index

HIV Human Immunodeficiency Virus

LGBTQI Lesbian, gay, bisexual, transgender, queer, and/or intersex

MSM Men who have sex with men

NIH National Institutes of Health

PICO Patient/Population/Problem, Intervention, Comparison, Outcome

SGM Sexual and gender minorities

QOL Quality of life

WSW Women who have sex with women

\section{Declarations}

\section{Ethics approval and consent:}

This article does not contain any studies with human participants or animals performed by any of the authors.

\section{Consent for publication:}

Not applicable.

\section{Availability of data and materials:}

Data sharing is not applicable to this article as no datasets were generated or analyzed during the current study.

\section{Competing interests:}

The authors declare they have no competing interests.

\section{Funding:}




\section{Authors contributions:}

MPC conceptualized and designed the study and wrote the majority of the manuscript. AA and CR-D provided feedback on methods and conclusions, reviewed articles from the EMBASE search, and contributed to manuscript revisions.

\section{Acknowledgements:}

The authors would like to thank Daniel Castillo for his assistance with the EMBASE search and Ruta Brazinskaite for her expert administrative support. Thank you to the American Society of Clinical Oncology Sexual and Gender Minority Task Force for initiating the working relationship of Drs. Pratt-Chapman and Alpert, which resulted in co-authorship on this paper.

\section{Authors' information:}

Mandi L. Pratt-Chapman, PhD is Associate Center Director, Patient Centered Initiatives and Health Equity for the GW Cancer Center. Carlos E. Rodriguez-Diaz, PhD is Associate Professor, Prevention and Community Health, GW Milken Institute School of Public Health. Ash Alpert, MD is a Hematology-Oncology Fellow at the Wilmot Cancer Institute, University of Rochester.

\section{Systematic Review registrations:}

Not applicable

\section{References}

1. Institute of Medicine (U.S.). Committee on Lesbian Gay Bisexual and Transgender Health Issues and Research Gaps and Opportunities. The health of lesbian, gay, bisexual, and transgender people: building a foundation for better understanding. Washington, DC: National Academies Press; 2011.

2. National Institutes of Health. Sexual and Gender Minority Research Office (SGMRO) website. https://dpcpsi.nih.gov/sgmro. Accessed January 5, 2020.

3. Griggs J, Maingi S, Blinder V, Denduluri N, Khorana AA, Norton L, et al. American Society of Clinical Oncology position statement: strategies for reducing cancer health disparities among sexual and gender minority populations. J Clin Oncol. 2017;35(19):2203-08 doi: $10.1200 / J C 0.2016 .72 .0441$

4. Wheldon CW, Schabath MB, Hudson J, Bowman Curci M, Kanetsky P, Vadaparampil ST, et al. Culturally competent care for sexual and gender minority patients at national cancer institute-designated comprehensive cancer centers. Lgbt Health. 2018;5(3):203-11 doi: 10.1089/lgbt.2017.0217

5. Poteat T, German D, Kerrigan D. Managing uncertainty: a grounded theory of stigma in transgender health care encounters. Soc Sci Med. 2013;84:22-9 doi: 10.1016/j.socscimed.2013.02.019

6. James SE, Herman JL, Rankin S, Keisling M, Mottet L, Anafi M. The Report of the 2015 U.S. Transgender Survey. 2016. https://www.transequality.org/sites/default/files/docs/USTS-Full-Report-FINAL.PDF. Accessed January 5, 2020.

7. Arksey H, O’Malley L. Scoping studies: towards a methodological framework. Int J Soc Res Methodol. 2005;8(1):19-32 doi: 10.1080/1364557032000119616

8. Tricco AC, Lillie E, Zarin W, O'Brien KK, Colquhoun H, Levac D, et al. PRISMA extension for scoping reviews (PRISMA-ScR): checklist and explanation. Ann Intern Med. 2018;169(7):467-73 doi: 10.7326/M18-0850

9. Russell AM, Galvin KM, Harper MM, Clayman ML. A comparison of heterosexual and LGBTQ cancer survivors' outlooks on relationships, family building, possible infertility, and patient-doctor fertility risk communication. J Cancer Surviv. 2016;10(5):935-42 doi: 10.1007/s11764-016-0524-9

10. Bazzi AR, Clark MA, Winter MR, Ozonoff A, Boehmer U. Resilience among breast cancer survivors of different sexual orientations. Lgbt Health. 2018;5(5):295-302 doi: 10.1089/lgbt.2018.0019 
11. Boehmer U, Mertz M, Timm A, Glickman M, Sullivan M, Potter J. Overweight and obesity in long-term breast cancer survivors: how does sexual orientation impact BMI? Cancer Invest. 2011;29(3):220-8 doi: 10.3109/07357907.2010.550664

12. Boehmer U, Cooley TP, Clark MA. Cancer and men who have sex with men: a systematic review. Lancet Oncol. 2012;13(12):E545-E53 doi: 10.1016/S1470-2045(12)70347-9

13. Boehmer U, Glickman M, Milton J, Winter M. Health-related quality of life in breast cancer survivors of different sexual orientations. Qual Life Res. 2012;21(2):225-36 doi: 10.1007/s11136-011-9947-y

14. Boehmer U, White JL. Sexual minority status and long-term breast cancer survivorship. Women Health. 2012;52(1):71-87 doi: 10.1080/03630242.2011.643349

15. Boehmer U, Timm A, Ozonoff A, Potter J. Explanatory factors of sexual function in sexual minority women breast cancer survivors. Ann Oncol. 2012;23(11):2873-78 doi: 10.1093/annonc/mds099

16. Boehmer U, Glickman M, Winter M, Clark MA. Breast cancer survivors of different sexual orientations: which factors explain survivors' quality of life and adjustment? Ann Oncol. 2013;24(6):1622-30 doi: 10.1093/annonc/mdt035

17. Boehmer U, Glickman M, Winter M, Clark MA. Lesbian and bisexual women's adjustment after a breast cancer diagnosis. J Am Psychiat Nurses. 2013;19(5):280-92 doi: 10.1177/1078390313504587

18. Boehmer U, Glickman M, Winter M, Clark MA. Long-term breast cancer survivors' symptoms and morbidity: differences by sexual orientation? J Cancer Surviv. 2013;7(2):203-10 doi: 10.1007/s11764-012-0260-8

19. Boehmer U, Ozonoff A, Timm A, Winter M, Potter J. After breast cancer: sexual functioning of sexual minority survivors. J Sex Res. 2014;51(6):681-89 doi: 10.1080/00224499.2013.772087

20. Boehmer U, Ozonoff A, Potter J. Sexual minority women's health behaviors and outcomes after breast cancer. Lgbt Health. 2015;2(3):221-27 doi: 10.1089/lgbt.2014.0105

21. Boehmer U, Tripodis Y, Bazzi AR, Winter M, Clark MA. Fear of cancer recurrence in survivor and caregiver dyads: differences by sexual orientation and how dyad members influence each other. J Cancer Surviv. 2016;10(5):802-13 doi: 10.1007/s11764-016-0526-7

22. Boehmer U, Stokes JE, Bazzi AR, Winter M, Clark MA. Dyadic stress of breast cancer survivors and their caregivers: are there differences by sexual orientation? Psycho-Oncology. 2018;27(10):2389-97 doi: 10.1002/pon.4836

23. Boehmer U, Gereige J, Winter M, Ozonoff A. Cancer survivors' access to care and quality of life: do sexual minorities fare worse than heterosexuals? Cancer-Am Cancer Soc. 2019;125(17):3079-85 doi: 10.1002/cncr.32151

24. Boehmer U, Stokes JE, Bazzi AR, Clark MA. Dyadic quality of life among heterosexual and sexual minority breast cancer survivors and their caregivers. Support Care Cancer. 2020;28(6):2769-78 doi: 10.1007/s00520-019-05148-7

25. Brown MT, McElroy JA. Sexual and gender minority breast cancer patients choosing bilateral mastectomy without reconstruction: "I now have a body that fits me". Women Health. 2018;58(4):403-18 doi: 10.1080/03630242.2017.1310169

26. Jabson JM, Donatelle RJ, Bowen D. Breast cancer survivorship: the role of perceived discrimination and sexual orientation. J Cancer Surviv. 2011;5(1):92-101 doi: 10.1007/s11764-010-0161-7

27. Jabson JM, Donatelle RJ, Bowen DJ. Relationship between sexual orientation and quality of life in female breast cancer survivors. J Womens Health (Larchmt). 2011;20(12):1819-24 doi: 10.1089/jwh.2011.2921

28. Jabson JM, Bowen DJ. Perceived stress and sexual orientation among breast cancer survivors. J Homosex. 2014;61(6):889-98 doi: 10.1080/00918369.2014.870814

29. Jabson JM, Farmer GW, Bowen DJ. Health behaviors and self-reported health among cancer survivors by sexual orientation. Lgbt Health. 2015;2(1):41-47 doi: 10.1089/lgbt.2014.0038

30. Kamen C, Jabson JM, Mustian KM, Boehmer U. Minority stress, psychosocial resources, and psychological distress among sexual minority breast cancer survivors. Health Psychol. 2017;36(6):529-37 doi: 10.1037/hea0000465

31. Mohr J, Fassinger R. Measuring dimensions of lesbian and gay male experience. Meas Eval Couns Dev. 2000;33(2):66-90 doi: Doi 10.1080/07481756.2000.12068999

32. Wheldon CW, Roberts MC, Boehmer U. Differences in coping with breast cancer between lesbian and heterosexual women: a life course perspective. J Womens Health (Larchmt). 2019;28(8):1023-30 doi: 10.1089/jwh.2018.6940

33. Baughman A, Clark MA, Boehmer U. Experiences and concerns of lesbian, gay, or bisexual survivors of colorectal cancer. Oncol Nurs Forum. 2017;44(3):350-57 doi: 10.1188/17.ONF.350-357

34. Allensworth-Davies D, Talcott JA, Heeren T, de Vries B, Blank TO, Clark JA. The health effects of masculine self-esteem following treatment for localized prostate cancer among gay men. Lgbt Health. 2016;3(1):49-56 doi: 10.1089/lgbt.2015.0090 
35. Capistrant BD, Torres B, Merengwa E, West WG, Mitteldorf D, Rosser BR. Caregiving and social support for gay and bisexual men with prostate cancer. Psycho-Oncology. 2016;25(11):1329-36 doi: 10.1002/pon.4249

36. Crangle CJ, Latini DM, Hart TL. The effects of attachment and outness on illness adjustment among gay men with prostate cancer. Psycho-Oncology. 2017;26(4):500-07 doi: 10.1002/pon.4043

37. Hart TL, Coon DW, Kowalkowski MA, Zhang K, Hersom JI, Goltz HH, al. Changes in sexual roles and quality of life for gay men after prostate cancer: challenges for sexual health providers. J Sex Med. 2014;11(9):2308-17 doi: 10.1111/jsm.12598

38. Hartman ME, Irvine J, Currie KL, Ritvo P, Trachtenberg L, Louis A, et al. Exploring gay couples' experience with sexual dysfunction after radical prostatectomy: a qualitative study. J Sex Marital Ther. 2014;40(3):233-53 doi: 10.1080/0092623X.2012.726697

39. Lee TK, Breau RH, Eapen L. Pilot study on quality of life and sexual function in men-who-have-sex-with-men treated for prostate cancer. J Sex Med. 2013;10(8):2094-100 doi: 10.1111/jsm.12208

40. Lee TK, Handy AB, Kwan W, Oliffe JL, Brotto LA, Wassersug RJ, et al. Impact of prostate cancer treatment on the sexual quality of life for men-who-have-sex-with-men. J Sex Med. 2015;12(12):2378-86 doi: 10.1111/jsm.13030

41. Hoyt MA, Frost DM, Cohn E, Millar BM, Diefenbach MA, Revenson TA. Gay men's experiences with prostate cancer: implications for future research. J Health Psychol. 2020;25(3):298-310 doi: 10.1177/1359105317711491

42. McConkey RW, Holborn C. Exploring the lived experience of gay men with prostate cancer: a phenomenological study. Eur J Oncol Nurs. 2018;33:62-69 doi: 10.1016/j.ejon.2018.01.013

43. Motofei IG, Rowland DL, Popa F, Kreienkamp D, Paunica S. Preliminary study with bicalutamide in heterosexual and homosexual patients with prostate cancer: a possible implication of androgens in male homosexual arousal. Bju Int. 2011;108(1):110-5 doi: 10.1111/j.1464-410X.2010.09764.x

44. Polter EJ, Wheldon CW, Rosser BRS, Kohli N, Capistrant BD, Kapoor A, et al. Health-related quality of life by human immunodeficiency virus status in a cross-sectional survey of gay and bisexual prostate cancer survivors. Psychooncology. 2019;28(12):2351-57 doi: 10.1002/pon.5228

45. Rosser BR, Capistrant B, Torres B, Konety B, Merengwa E, Mitteldorf D, et al. The effects of radical prostatectomy on gay and bisexual men's mental health, sexual identity and relationships: qualitative results from the Restore Study. Sex Relation Ther. 2016;31(4):446-61 doi: 10.1080/14681994.2016.1228871

46. Thomas C, Wootten A, Robinson P. The experiences of gay and bisexual men diagnosed with prostate cancer: results from an online focus group. Eur J Cancer Care. 2013;22(4):522-29 doi: 10.1111/ecc.12058

47. Thomas C, Wootten AC, Robinson P, Law PCF, McKenzie DP. The impact of sexual orientation on body image, self-esteem, urinary and sexual functions in the experience of prostate cancer. Eur J Cancer Care. 2018;27(2) doi: ARTN e1282710.1111/ecc.12827

48. Torbit LA, Albiani JJ, Crangle CJ, Latini DM, Hart TL. Fear of recurrence: the importance of self-efficacy and satisfaction with care in gay men with prostate cancer. Psycho-Oncology. 2015;24(6):691-98 doi: 10.1002/pon.3630

49. Ussher JM, Perz J, Kellett A, Chambers S, Latini D, Davis ID, et al. Health-related quality of life, psychological distress, and sexual changes following prostate cancer: a comparison of gay and bisexual men with heterosexual men. J Sex Med. 2016;13(3):425-34 doi: 10.1016/j.jsxm.2015.12.026

50. Ussher JM, Perz J, Rose D, Dowsett GW, Chambers S, Williams S, et al. Threat of sexual disqualification: the consequences of erectile dysfunction and other sexual changes for gay and bisexual men with prostate cancer. Arch Sex Behav. 2017;46(7):2043-57 doi: 10.1007/s10508-016-0728-0

51. Wassersug RJ, Lyons A, Duncan D, Dowsett GW, Pitts M. Diagnostic and outcome differences between heterosexual and nonheterosexual men treated for prostate cancer. Urology. 2013;82(3):565-71 doi: 10.1016/j.urology.2013.04.022

52. Wright MM, Schreiner P, Rosser BRS, Polter EJ, Mitteldorf D, West W, et al. The influence of companion animals on quality of life of gay and bisexual men diagnosed with prostate cancer. Int J Environ Res Public Health. 2019;16(22) doi: 10.3390/ijerph16224457

53. Boehmer U, Miao XP, Ozonoff A. Cancer survivorship and sexual orientation. Cancer-Am Cancer Soc. 2011;117(16):3796-804 doi: 10.1002/cncr.25950

54. Bryson MK, Taylor ET, Boschman L, Hart TL, Gahagan J, Rail G, et al. Awkward choreographies from cancer's margins: incommensurabilities of biographical and biomedical knowledge in sexual and/or gender minority cancer patients' treatment. $J$ Med Humanit. 2018 doi: 10.1007/s10912-018-9542-0

55. Kamen C, Palesh O, Gerry AA, Andrykowski MA, Heckler C, Mohile S, et al. Disparities in health risk behavior and psychological distress among gay versus heterosexual male cancer survivors. Lgbt Health. 2014;1(2):86-U103 doi: 10.1089/lgbt.2013.0022 
56. Kamen C, Mustian KM, Dozier A, Bowen DJ, Li Y. Disparities in psychological distress impacting lesbian, gay, bisexual and transgender cancer survivors. Psycho-Oncology. 2015;24(11):1384-91 doi: 10.1002/pon.3746

57. Kamen CS, Smith-Stoner M, Heckler CE, Flannery M, Margolies L. Social support, self-rated health, and lesbian, gay, bisexual, and transgender identity disclosure to cancer care providers. Oncol Nurs Forum. 2015;42(1):44-51 doi: 10.1188/15.0NF.44-51

58. Kamen C, Heckler C, Janelsins MC, Peppone LJ, McMahon JM, Morrow, GR, et al. A dyadic exercise intervention to reduce psychological distress among lesbian, gay, and heterosexual cancer survivors. LGBT Health. 2016;3(1), 57-64.

doi:10.1089/lgbt.2015.0101

59. Lisy K, Ward A, Schofield P, Hulbert-Williams N, Bishop J, Jefford M. Patient-reported outcomes of sexual and gender minority cancer survivors in Australia. Psycho-Oncology. 2019;28(2):442-44 doi: 10.1002/pon.4956

60. Matthews AK, Hotton A, Li CC, Miller K, Johnson A, Jones KW, et al. An internet-based study examining the factors associated with the physical and mental health quality of life of LGBT cancer survivors. Lgbt Health. 2016;3(1):65-73 doi: 10.1089/lgbt.2014.0075

61. Antoni MH, Lehman JM, Kilbourn KM, Boyers AE, Culver JL, Alferi SM, et al. Cognitive-behavioral stress management intervention decreases the prevalence of depression and enhances benefit finding among women under treatment for early-stage breast cancer. Health Psychol. 2001;20(1):20-32 doi: 10.1037//0278-6133.20.1.20

62. Frierson GM, Thiel DL, Andersen BL. Body change stress for women with breast cancer: the Breast-Impact of Treatment Scale. Ann Behav Med. 2006;32(1):77-81 doi: 10.1207/s15324796abm3201_9

63. Derogatis LR, Melisaratos N. The Brief Symptom Inventory: an introductory report. Psychol Med. 1983;13(3):595-605

64. Schulz U, Schwarzer R. Soziale Unterstützung bei der Krankheitsbewältigung: Die Berliner Social Support Skalen (BSSS) [Social support in coping with illness: the Berlin Social Support Scales (BSSS)]. Diagnostica. 2003;49(2):73-82 doi: 10.1026//00121924.49.2.73

65. Lubeck DP, Litwin MS, Henning JM, Stier DM, Mazonson P, Fisk R, et al. The CaPSURE database: a methodology for clinical practice and research in prostate cancer. CaPSURE Research Panel. Cancer of the Prostate Strategic Urologic Research Endeavor. Urology. 1996;48(5):773-7 doi: 10.1016/s0090-4295(96)00226-9

66. Radloff LS. The CES-D scale: a self report depression scale for research in the general population. Appl Psychol Meas. 1977;1(3):385401 doi: https://doi.org/10.1177/014662167700100306

67. UCLA Center for Health Policy Research. California Health Interview Survey. 2012. http://healthpolicy.ucla.edu/chis/Pages/default.aspx. Accessed January 5, 2020.

68. Keller A, McGarvey EL, Clayton AH. Reliability and construct validity of the Changes in Sexual Functioning Questionnaire short-form (CSFQ-14). J Sex Marital Ther. 2006;32(1):43-52 doi: 10.1080/00926230500232909

69. Spanier GB. Measuring dyadic adjustment: new scales for assessing the quality of marriage or similar dyads. J Marriage Fam. 1976;38(1):15-28 doi: 10.2307/350547

70. Clark JA, Bokhour BG, Inui TS, Silliman RA, Talcott JA. Measuring patients' perceptions of the outcomes of treatment for early prostate cancer. Med Care. 2003;41(8):923-36 doi: 10.1097/00005650-200308000-00006

71. Vinokur AD, van Ryn M. Social support and undermining in close relationships: their independent effects on the mental health of unemployed persons. J Pers Soc Psychol. 1993;65(2):350-9 doi: 10.1037//0022-3514.65.2.350

72. Wei JT, Dunn RL, Litwin MS, Sandler HM, Sanda MG. Development and validation of the expanded prostate cancer index composite (EPIC) for comprehensive assessment of health-related quality of life in men with prostate cancer. Urology. 2000;56(6):899-905 doi: 10.1016/s0090-4295(00)00858-x

73. Esper P, Mo F, Chodak G, Sinner M, Cella D, Pienta KJ. Measuring quality of life in men with prostate cancer using the functional assessment of cancer therapy-prostate instrument. Urology. 1997;50(6):920-8 doi: 10.1016/S0090-4295(97)00459-7

74. Rosen R, Brown C, Heiman J, Leiblum S, Meston C, Shabsigh R, et al. The Female Sexual Function Index (FSFI): a multidimensional self-report instrument for the assessment of female sexual function. J Sex Marital Ther. 2000;26(2):191-208 doi: $10.1080 / 009262300278597$

75. Zigmond AS, Snaith RP. The hospital anxiety and depression scale. Acta Psychiatr Scand. 1983;67(6):361-70 doi: 10.1111/j.16000447.1983.tb09716.x

76. Rosen RC, Riley A, Wagner G, Osterloh IH, Kirkpatrick J, Mishra A. The international index of erectile function (IIEF): a multidimensional scale for assessment of erectile dysfunction. Urology. 1997;49(6):822-30 doi: 10.1016/s0090-4295(97)00238-0

77. Devins GM, Dion R, Pelletier LG, et al. Structure of lifestyle disruptions in chronic disease: a confirmatory factor analysis of the Illness Intrusiveness Ratings Scale. Med Care. 2001;39(10):1097-104 doi: 10.1097/00005650-200110000-00007

Page 31/34 
78. Cohen S, Hoberman HM. Positive events and social supports as buffers of life change stress. J. Appl. Soc. Psychol. 1983;13(2):99-125 doi: doi:10.1111/j.1559-1816.1983.tb02325.x

79. Watson M, Law, M., dos-Santos, M., Greer, S., Baruch, J., \& Bliss, J. M. The mini MAC: further development of the mental adjustment to cancer scale. J Psychosoc Oncol. 1994;12(3):33-46 doi: 10.1300/J077V12N03_03

80. Aaronson NK, Ahmedzai S, Bergman B, Bullinger M, Cull A, Duez NJ, et al. The European Organization for Research and Treatment of Cancer QLQ-C30: a quality-of-life instrument for use in international clinical trials in oncology. J Natl Cancer Inst. 1993;85(5):365-76 doi: 10.1093/jnci/85.5.365

81. Roth AJ, Rosenfeld B, Kornblith AB, Gibson C, Scher HI, Curley-Smart T, et al. The memorial anxiety scale for prostate cancer: validation of a new scale to measure anxiety in men with with prostate cancer. Cancer-Am Cancer Soc. 2003;97(11):2910-8 doi: $10.1002 /$ cncr.11386

82. Cash T. Manual for the Multidimensional Body-Self Relations Questionnaire (MBSRQ) (3rd rev.). 2000. http://www.body-images.com. Accessed January 5, 2020.

83. Rosen RC, Catania JA, Althof SE, Pollack LM, O'Leary M, Seftel AD, et al. Development and validation of four-item version of Male Sexual Health Questionnaire to assess ejaculatory dysfunction. Urology. 2007;69(5):805-9 doi: 10.1016/j.urology.2007.02.036

84. Zimet GD, Dahlem NW, Zimet SG, Farley GK. Multidimensional scale of perceived social support (MSPSS). J Pers Assess. 1988;52(1):30-41 doi: 10.1207/s15327752jpa5201_2

85. Centers for Disease Control and Prevention. National Health and Nutrition Examination Survey Data. Atlanta, GA U.S; 2008.

86. Cohen S, Wills TA. Stress, social support, and the buffering hypothesis. Psychol Bull. 1985;98(2):310-57

87. Ferrell BR, Hassey-Dow K, Grant M. Quality of Life Patient/Cancer Survivor Version (QOL-CSV). 2012. www.midss.ie. Accessed January $5,2020$.

88. Wagnild GM, Young HM. Development and psychometric evaluation of the Resilience Scale. J Nurs Meas. 1993;1(2):165-78

89. Bartholomew K, Horowitz LM. Attachment styles among young adults: a test of a four-category model. J Pers Soc Psychol. 1991;61(2):226-44 doi: 10.1037//0022-3514.61.2.226

90. Ware J, Kosinski M, Keller SD. A 12-Item Short-Form Health Survey: construction of scales and preliminary tests of reliability and validity. Med Care. 1996;34(3):220-33 doi: 10.1097/00005650-199603000-00003

91. Ware J, Kosinski M, Keller S. SF-36 physical and mental health summary scales: a user's manual. Boston, MA: The Health Institute, New England Medical Center; 1994.

92. Spielberger C, Gorsuch R, Lushene R. The State-Trait Anxiety Inventory (STAI): Palo Alto, CA: Consulting Psychologists Press; 1968.

93. Anderson LA, Dedrick RF. Trust in Physician Scale (TPS). Measures for clinical practice: Vol. 2. Adults New York, NY: The Free Press; 1990.

94. Kent EE, Wheldon CW, Smith AW, Srinivasan S, Geiger AM. Care delivery, patient experiences, and health outcomes among sexual and gender minority patients with cancer and survivors: a scoping review. Cancer-Am Cancer Soc. 2019;125(24):4371-79 doi:

10.1002/cncr.32388

\section{Figures}




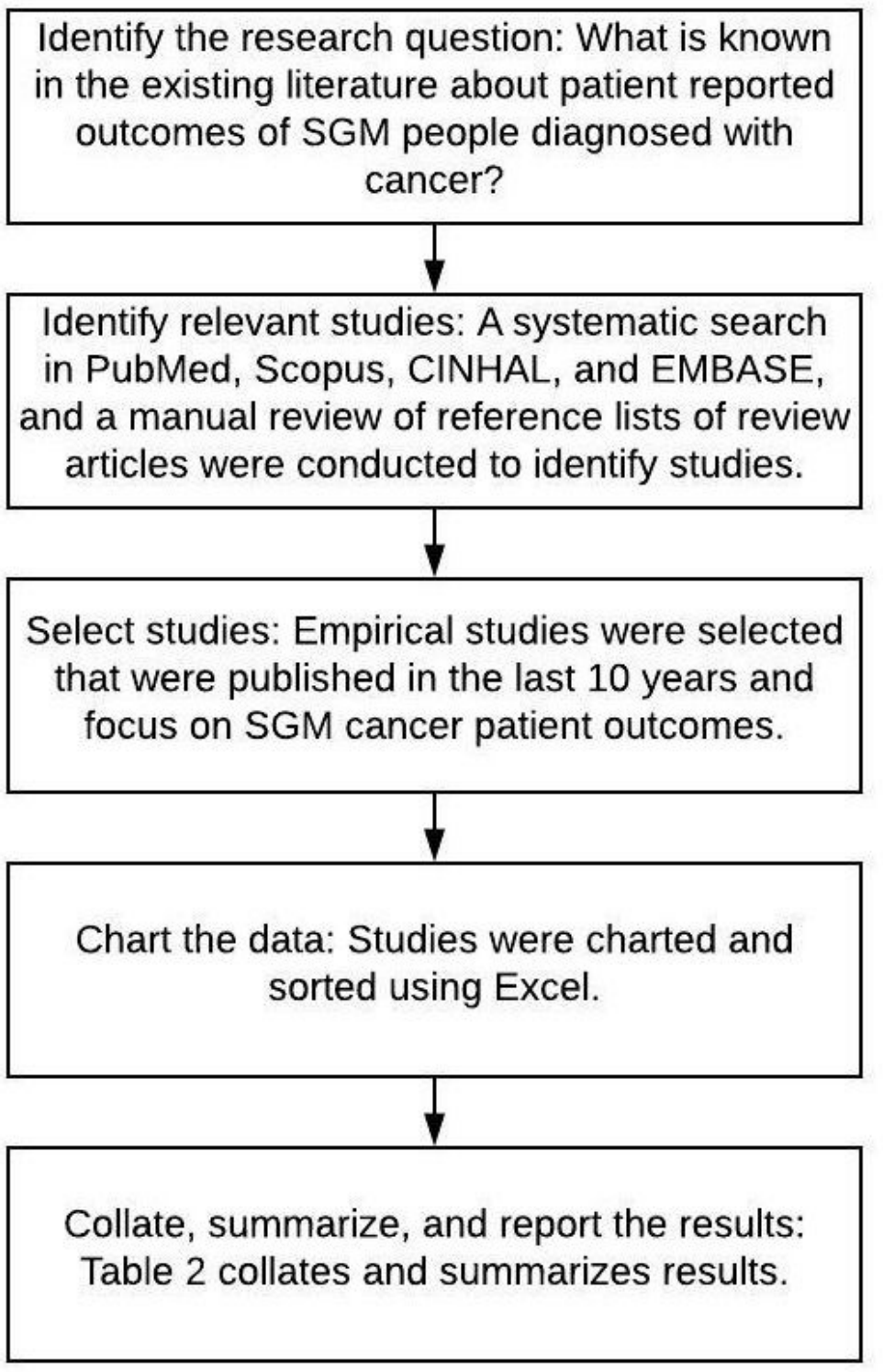

Figure 1

Flow chart of Scoping Review Process 


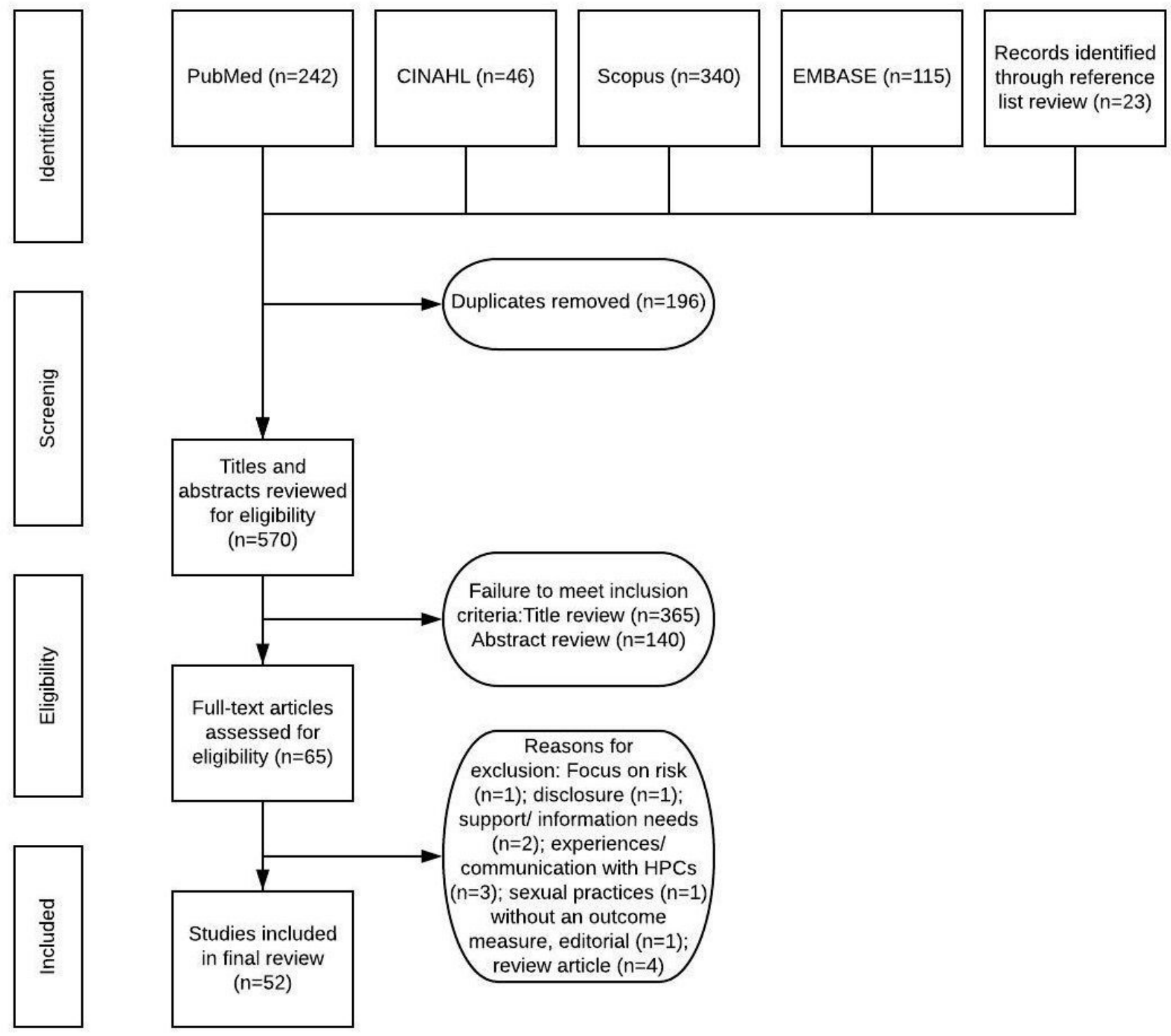

Figure 2

PRISMA Diagram of Study Selection

\section{Supplementary Files}

This is a list of supplementary files associated with this preprint. Click to download.

- PRISMAScRFillableChecklist.pdf

- Appendix.pdf 